\title{
Aristoteles'in Poetika'sı Bağlamında İslam Dünyasında Tragedya: Yunanca, Süryanice, Arapça Tercüme, Şerh, Telhis Sürecinde Tragedya
}

\author{
Ayşe Taşkent \\ Dr. Öğr. Üyesi, İstanbul Üniversitesi-Cerrahpaşa, Eğitim Fakültesi, Resim-İş Eğitimi Ana Bilim \\ Dalı \\ İstanbul/Türkiye \\ ayse.taskent@istanbul.edu.tr \\ http://orcid.org/0000-0003-0852-3802
}

\begin{abstract}
Öz: Aristoteles'in Poetika adlı eseri 9. yy. sonu ile 10. yy.'ın başlarında Süryaniceye tercüme edilmiştir. Ebû Bişr Mettâ b. Yûnus el-Kunnâî (Yûnânî) (ö.940) tarafından ise Süryaniceden Arapçaya tercüme edilmiştir. Günümüze ulaşan bu tercüme Paris'te Bibliotheque Nationale Arapça yazmalar kısmında 2346 sayısıyla numaralandırılmıştır. Bu Arapça tercümenin yanı sıra Poetika'nın Süryanice-Aramice tercümesinin küçük bir parçası günümüze ulaşabilmiştir. Tragedya hakkındaki bu Süryanice fragman, Severus bar Şakko'nun (Yackûub bar Şakko) (ö. 1241) "Diyaloglar Kitabı"nda ('Ktaba da-Dyalogo) yer almaktadır. Makalemizde "Poetika'nın Süryaniceden Arapçaya ilk tercümeleri hakkında bilgi verilerek Severus Bar Şakko'nun Süryanice fragmanında ve Mettâ b. Yûnus'un Poetika tercümesinde tragedyanın nasıl tanımlandığı Aristoteles'in tragedya tanımlaması ile karşılaştırılmalı olarak incelenecektir. Mettâ b. Yûnus (ö.940) ve İbn Rüşd'de (ö. 520/1126) medih sanat1; Fârâbî (ö. 339/950) ve İbn Sînâ'da (ö. 428/1037) ise tragedya olarak anılan söz konusu türün nitel ve nicel analizi yapılacaktır. Tragedyanın nitel analizinde Aristoteles'in Poetika'sında yer verilen tragedyanın altı ögesi; muthos (öykü), ethos (karakter), leksis (sözel ifade), dionoia (düşünce), opsis (sahne düzeni), harmonia (harmoni) ele alınacaktır. Nicel analizinde ise "prolog, episodlar, eksodos, koro şarkısı” ögeleri ele alınarak nitel ve nicel ögelerin Mettâ b. Yûnus, İbn Sînâ ve İbn Rüşd'ün eserlerine nasıl nakl edildiği ve nasıl yorumlandığı incelenecektir.
\end{abstract}

Anahtar Kelimeler: İslam Felsefesi, Aristoteles, Poetika, Severus bar Şakko, Ebû Bişr Mettâ b. Yûnus el-Kunnâî, Fârâbî, İbn Sînâ, İbn Rüşd, Tragedya, Medih Sanatı.

Geliş Tarihi/Received Date: 03.03.2021

Kabul Tarihi/Accepted Date: 27.05.2021

\section{Araştırma Makalesi/Research Article}

Atıf/Citation: Taşkent, Ayşe. “Aristoteles'in Poetika'sı Bağlamında İslam Dünyasında Tragedya: Yunanca, Süryanice, Arapça Tercüme, Şerh, Telhis Sürecinde Tragedya ”. Uludağ Üniversitesi İlahiyat Fakültesi Dergisi 30/1 (Haziran 2021), 105-134. https://doi.org/10.51447/uluifd.890420 


\title{
Tragedy in the Islamic World in the Context of Aristotle's Poetics: Tragedy in Greek, Syriac, and Arabic Translations, Commentaries, and Summaries
}

\begin{abstract}
Aristotle's Poetics was translated into Syriac by the late ninth or early tenth century and, within a few decades, was translated again from Syriac into Arabic by Abū Bišr Mattā ibn Yūnus (d. 940). The Arabic translation survives almost intact in the codex Parisinus Ar. 23463 , but only a passage of about thirty lines survives from the Syriac translation (this passage is quoted in Jacob bar Šakko's Book of Dialogues). This article gives information about the first translations of Poetics from Syriac into Arabic and compares the definition of tragedy in Šakkō's Syriac fragment and Abū Bišrs's translation of Poetics against Aristotle's definition of tragedy. It qualitatively and quantitatively analyzes the genre described as the art of madịh in Abū Bišr and Ibn Rushd (d. 520/1126) and as tragedy in al-Fārābī (d. 339/950) and Ibn Sīnā (d. 428/1037). In its qualitative analysis of tragedy, it discusses six elements of tragedy in Aristotle's Poetics: muthos (myth), ethos (character), lexis (measure), dionoia (thought), opsis (spectacle), and harmonia (harmony). In its quantitative analysis, it examines the elements of prologue, episode, exodos, and choral song, as well as how qualitative and quantitative elements were transmitted to and interpreted in the works of Abu Bišr, Ibn Sīnā, and Ibn Rushd.
\end{abstract}

Keywords: Islamic Philosophy, Aristotle, Poetics, Jacob bar Šakko, Abū Bišr Mattā ibn Yūnus, al-Fārābī, Ibn Sīnā (Avicenna), Ibn Rushd (Averroes), Tragedy, The Art of Madīh .

[You may find an extended abstract of this article after the bibliography.]

\section{Giriş}

Aristoteles'in mantık külliyatı Organon'a sekizinci ve son kitap olarak eklenen Poetika adlı eserin günümüze ulaşan en eski versiyonu, Ebû Bişr Mettâ b. Yûnus elKunnâî (Yûnânî) (ö. 328/940) tarafından Süryaniceden Arapçaya yapılan tercümedir. Aristoteles, Poetika'da tragedya, komedya ve ditrambos gibi farklı Yunan sanat formlarını, tragedyayı merkeze alarak açıklamış iken; İslam filozofları, Aristoteles'ten farklı olarak şiiri hem şekli hem de mahiyeti itibariyle mantık alanına dâhil ederek, daha özelde ise bir kıyas türü olarak ele almışlardır. ${ }^{1}$ Fârâbî, İbn Sînâ ve İbn Rüşd'ün Aristoteles'in Poetika'sı üzerine telif ettikleri eserler, Organon külliyâtına dâhil edilmesi bakımından Mantık çalışmaları içinde değerlendirmiştir. Fârâbî, İbn Sînâ ve İbn Rüşd'ün eserlerindeki Yunan sanatları özellikle tragedya hakkındaki yaklaşımları henüz yeterince açıklanmamıştır. Filozoflar metinlerinde, Yunanlıların şiir türleri olarak niteledikleri "tragedya, dîsirambî/ditrambos, komedyâ,

1 Deborah L. Black, Logic and Aristotle's Rhetoric and Poetics in Mediavel Arabic Philosophy (Leiden: E.J. Brill, 1990), 180-183; Kemal Sâlim, The Philosophical Poetics of Alfârâbî, Avicenna and Averroes, The Aristotelian Reception (London-New York: Routledge Curzon, 2000), 87; Ayşe Taşkent, Güzelin Peşinde Fârâbî, îbn Sînâ ve İbn Rüşd'de Estetik (İstanbul: Klasik, 2012), 237-283. 
İyâmbû/iambik şiir, drâmâtâ" gibi edebî ve teatral türler hakkında uzun açıklamalar ve tartışmalar yapmaktadır. Makalemizde henüz üzerinde yeterince çalışılmamış olan Aristoteles'in Poetika'sında yer alan "tragedya" sanatının Mettâ b. Yûnus, İbn Sînâ ve İbn Rüşd'ün Poetikalarında nasıl ele alındığı incelenecektir. Bunun yanı sıra Poetika'nın Süryanice-Aramice tercümesinin günümüze ulaşabilmiş küçük bir parçası ile karşılaştırmalar yapılacaktır. Tragedya hakkındaki bu Süryanice fragman, Severus bar Şakko'nun (Yackûb bar Şakko) (ö. 1241) "Diyaloglar Kitabı”nda ('Ktaba da-Dyalogo) yer almaktadır. Aristoteles'in tragedya tanımının en erken örneği kabul edilen bu Süryanice fragman; Poetika'nın hem Yunancadan Süryaniceye hem de Süryaniceden Arapçaya çevrilmesi sürecini takip etme imkânı verdiğinden önem taşımaktadır. Bu metin ayrıca Poetika'nın Yunanca orijinaline ulaşma imkânını bulamamış İslam filozoflarının iki aşamalı bir tercüme sürecinden (Süryanice, Arapça) geçmiş bir metni nasıl yorumladıkları hakkında da aydınlatıcı olacaktır. Makalemizin birinci bölümünde “Poetika'nın Süryaniceden Arapçaya ilk tercümeleri hakkında bilgi verilecek, ikinci bölümde Severus Bar Şakko'nun Süryanice Fragmanında ve Mettâ B. Yûnus'un Poetika tercümesinde tragedyanın nasıl tanımlandığına bakılacak ve Aristoteles'in tragedya tanımlaması ile karşılaştırılacaktır. Üçüncü ve dördüncü bölüm, Fârâbî ve İbn Sînâ'da tragedya; Mettâ b. Yûnus ve İbn Rüşd'de ise medih sanatı üzerinden tartışılan tragedya ve medih sanatının incelenmesine ayrilmıştır. Makalemizde son olarak tragedya ve medhin nitel ve nicel analizi yapılacaktır.

\section{Poetika'nın Süryaniceden Arapçaya İlk Tercümeleri}

Aristoteles'in Poetika'sının günümüze ulaşan en eski versiyonu Ebû Bişr Mettâ b. Yûnus el-Kunnâî (Yûnânî) (ö. 328/940) tarafından Süryaniceden Arapça yapılan tercümedir. ${ }^{2}$ Bu tercüme Paris'te Bibliotheque Nationale Arapça yazmalar kısmında 2346 sayısıyla numaralandırılmıştır (2346 arabe (fol. 131a-146b). ${ }^{3} 932$ tarihinde

2 Ebû Bişr Mettâ b. Yûnus'un Süryaniceden Arapçaya yaptığg tercümenin dört neşri vardır: Samuel Margoliouth, Analecta Orientalia ad Poeticam Aristoteleam (London: D. Nutt, 1887), 1-76; Jaroslaus Tkatsch, Die arabische Übersetzung der Poetik des Aristoteles (Vienna: Akademie der Wissenschaften, 1928, 1932); Şükrî Muhammed Ayyâd, Kitâbu Aristotâlis fiş-Şi'r nakl Ebî Bişr Mettâ b. Yûnus el-Kunnâ̂̂ min'el Süryânî ile'l-Arabî (Kahire: Dâr el-Kitâb el-'Arabî, 1967), 29-157; Abdurrahman Bedevî, Aristûtâlis Fennü'ş-Şi'r, mea' tercemeti'l Arabiyyeti'l kadîmeti ve şurûhi'l-Fârâbî, İbn Sînâ ve İbn Rüşd (Beyrut: Daru's sakafe, 1953), 85-143.

3 Leonardo Tarán vd., Aristotle Poetics, Editio Maior of the Greek Text with Historical Introductions and Philological Commentaries (Leiden-Boston: Brill, 2012), 36, 64, 144; Bedevî, Fennü’ş-Şír, 51; İsmail M. Dahiyat, Avicenna's Commentary on the Poetics of Aristotle: A Critical Study with an Annotated Translation of the Text (Leiden: E. J. Brill, 1974), 4; Lutz Edzard vd., "A new look at the Greek, Syriac, and Arabic versions of Aristotle's Poetics", Grammar as a window onto Arabic Humanism. A Collection of Articles in Honour of Michael G. Carter, ed. Lutz Edzard- Janet Watson (Harrassowitz: Wiesbaden, 2006), 222-264, 222; Alberto Rigolio, “Aristotle's Poetics in Syriac and in Arabic Translations: Readings of Tragedy”, 
Mettâ'nın yaptığı bu tercüme yaklaşık 700 yılından öncesine ait olan kayıp bir Yunanca elyazmasının Süryanice-Aramice tercümesi üzerine temellenir. Poetika'nın Süryanice-Aramice tercümesinden otuz satırlık sadece bir paragraf (ch.6. 1449b241450a9) günümüze ulaşmıştır. Aristoteles'in tragedya tanımının en erken örneği bu Süryanice kaynaktan alınmıştır. Tragedya hakkındaki bu Süryanice fragman Musul yakınlarındaki bir manastırda piskopos olan Severus bar Şakko'nun (ö. 1241) “Diyalog-

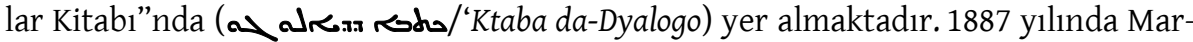
goliouth Analecta orientalia ad Poeticam Aristoteleam, adlı çalışmasında bu tercümeyi neşretmiştir. ${ }^{4}$

Mettâ b. Yûnus'un Poetika tercümesi orjinal metne mutabık olmaması bakımından eleştirilmekte; Aristoteles'in metnini yanlış anladı̆̆ı, dönüştürdüğü ifade edilmekte ve çoğunlukla zor anlaşılan ya da anlaşılmaz bir metin olarak nitelenmektedir..$^{5}$ Aristoteles'in Poetika'sının konusunu oluşturan Yunan sanatlarına aşina olmaması, ana dili Süryanice olan Mettâ'nın Arap dilindeki yetersizliği tercüme hakkında verilen olumsuz yargilarda rol oynamıştır. ${ }^{6}$ Metinde Süryanice, Yunanca, Arapça, Farsça gibi farklı dillerden alınmış kavramların kullanılması, metnin bu çok dilli yapısı olumsuz karşılanmış ve farklı diller içinde ifade edilmek istenen şeylerin mütercimi zorladığı ifade edilmiştir. Bu olumsuz düşüncelere karşın Mettâ'nın tercümesinin asıl metnin içeriğini taşıdığı, aslını taklit ettiği ona benzediği ve anlatılan pek çok konuya değindiği de ifade edilmektedir. Mütercim metinde anlatılan içeriği doğru okumak ve anlamlandırmak için metnin iç yapı ve akışından ayrılmamakta, metinden kopmaksızın asıl metni tercüme etmektedir. Ortaya konan ifadeler; hatalı, çelişkili, tartışmalı olsa da söylenilen şeylerin arkasına gizlenen mana, asıl metnin rengini almakta, asıl metnin hacmine ve içeriğine uygunluk arz etmektedir. ${ }^{7}$

Mettâ b. Yûnus'un Poetika tercümesinin yanı sıra Süryanice ve Arapça Poetika mütercimleri hakkında iki isim daha zikredilmektedir: İshak b. Huneyn (ö. 910) ${ }^{8}$ ve

Khristianskii Vostok 6 (Христианский Bосток NS 6) (Moscow: Russiian Academy of Sciences, 2013), 140-149, 140.

4 Edzard vd., "A new look at the Greek, Syriac, and Arabic versions of Aristotle’s Poetics”, 222; Tarán vd., Aristotle Poetics, 77-114; Rigolio, Aristotle's Poetics, 140.

5 Muhammed Latifî el-Yusufî, eş-Şi'r ve'ş-şi'riyyeh, el-felâsife ve'l-müfekkirûne'l-Arab (Dâr'ul-Arabiyyet'ül Kitab, 1992), 179; Ayyâd, Kitâbu Aristotâlis fiş-Şi'r nakl Ebî Bişr Mettâ b. Yûnus el-Kunnâî min'el Süryânî ile'l-Arabî, 177-179.

6 Rigolio, Aristotle's Poetics, 140.

7 el-Yusufî, eş-Şi'r ve'ş-şi'riyyeh, el-felâsife ve'l-müfekkirûne'l-Arab, 179.

8 Bedevî, Aristûtâlis Fennü̈ş-Şi'r, 51,52; Ayşe Taşkent, İbn Sînâ ve Fârâbînin Poetikaları Aristoteles'in Poetika'sının İslam Dünyasındaki Yansımaları (Ankara: Türkiye Bilimler Akademisi, 2019), 23; İbnü'nNedîm'in Fihrist'inde İskender el-Afrodîsî (Aphrodisias) bölümündeki açıklamaları Poetika'nın İshak tarafından tercüme edildiğine delil olarak gösterilmiştir: “Aristo'dan bahsederken Aristo'nun kitaplarına yaptı̆̆ı şerhten bahsetmiştik. Ebû Zekeriyyâ Yahyâ b. Adî şöyle der: İskender el-Afrodîsînnin Semâ Şerhi'ni, Kitâbü'l-Burhân Şerhi'nin tamamını Hıristiyan mütercim İbrâhim b. Abdullah'ın te- 
Yahyâ b. Adî (ö. 975). ${ }^{9}$ Zikredilen bu üç mütercim içerisinde 934 tarihinden önceki bir tarihte günümüze ulaşan Ebû Bişr Mettâ b. Yûnus tarafından yapılan Süryaniceden Arapçaya tercümesi kesin olarak bilinmektedir. ${ }^{10}$ Süryanice ve Arapça nakiller konusunda kimi veriler uzlaştırılmış ve Süryanice tercümenin İshak b. Huneyn tarafından yapıldığı ve Metta'nın metninin ikinci bir Arapça revizyonunun ise Yahyâ b. Adî tarafindan yapılmış olduğu sonucuna ulaşılmıştır. ${ }^{11}$

Mettâ'nın ilk Süryanice tercümesi 9. yy. ortalarından sonraki bir tarihte yapılmış; Yahyâ b. Adî’nin ikinci Arapça revizyon ise 11. yy. da İbn Sînâ'ya ulaşmıştır. İbn Sînâ, yaklaşık 1020'lerde kendi yorumlarını yazarken Mettâ b. Yûnus'un Arapça versiyonunun yanı sıra eserin ikinci revizyonu olan Yahyâ b. Adî'nin tercümesini de kullanmıştır. ${ }^{12}$ İbn Rüşd (ö.1198) ise Poetika'nın Telhîs'inde (Telhîs Aristutâlis Fi'ş'irOrta Şerh) Mettâ'nın metnini kullanmıştır. ${ }^{13}$

13. yüzyll Süryani metropoliti Barhebraeus'un (ö.1286) Aristoteles'in Poetika'sından kimi parçaların yer aldığı Ktābā d-hēwat hekmţā' (Hikmetin Özü Kitabı) başlıklı Süryanice bir eser yazmıștır. ${ }^{14}$ Barhebraeus bu eserini yazarken Süryanice

rekesinde gördüm. Her iki şerh bana 120 dinara teklif edildi. Altınları temin etmek için gittim. Döndüğümde bazı kitaplarla beraber Horasanlı bir adama 3000 dinara sattıklarını gördüm. İtimat ettiğim başka biri bana bu kitapların yende taşındığını söyledi. Ebû Zekeriyyâ İbrâhim b. Abdullah'tan Sofistika, el-Hitâbe, eş-Şiir (fassı'ş-şir) adlı kitapların metinlerinin İshak [b. Huneyn] tercümelerini 50 dinara satın almak istediğini, fakat onun satmadığını, ölmeden kitapları yaktığını söyledi."; Muhammed b. İshak En-Nedim, El-Fihrist, çev. Ramazan Şeşen (İstanbul: Türkiye Yazma Eserler Kurumu Başkanlığı Yayınları, 2019), 820; Ayyâd, Kitâbu Aristotâlis fiş-Şi'r nakl Ebî Bişr Mettâ b. Yûnus el-Kunnâ̂ min'el Süryânî ile'l-Arabî, 168-177; Dimitri Gutas, "The Poetics in Syriac and Arabic Transmission", Aristotle Poetics Editio Maior of the Greek Text with Historical Introductions and Philological Commentaries, ed. Leonardo Tarán vd. (Leiden, The Netherlands: Brill, 2012), 91.

9 Gutas, "The Poetics in Syriac and Arabic Transmission", 96; Bedevî, Aristûtâlis Fennü̈ş-Şirr, 51, 52; Edzard vd., "A new look at the Greek, Syriac, and Arabic versions of Aristotle's Poetics”, 224; Gerhard Endress, The Works of Yahyâ Ilon 'Adi: an Analytical Inventory (Wiesbaden: Reichert, 1977), 28; Taşkent, İbn Sînâ ve Fârâbînin Poetikaları Aristoteles'in Poetika'sının İslam Dünyasındaki Yansimaları, 21-22.

10 İbnü'n-Nedîm, Fihrist'te Aristo'nun Mantığa Dair Sekiz Kitabı içinde “Epütokya ve Poetika” tercümeleri hakkındaki bilgi vermekte ve Ebu Bişr Mettâ’nın Poetika'yı Süryaniceden Arapçaya çevirdiğini teyid etmektedir. Bunun yanıra Yahyâ b. Adî tercümesi olduğunu da ifade etmektedir. "Epotika (Poetika) [Hakkında Söz]: Manası şiir demektir. Eseri Ebu Bişr Mettâ Süryaniceden Arapçaya çevirdi. Yahyâ b. Adî tercümesi vardır. Themistius'un eser hakkında mütalaası bulunur. Bu mütalaanın sahte olduğu söylenir. el-Kindi'nin de muhtasarı vardır.”; Nedim, El-Fihrist, 812; Gutas, “The Poetics In Syriac And Arabic Transmission", 92.

11 Ayyâd, Kitâbu Aristotâlis fiş-Şir, 177-180; Bedevî, Fennü’ş-Şirr, 51-53; Gutas, "The Poetics In Syriac and Arabic Transmission", 148.

12 Lenn E. Goodman, Avicenna: Arabic Thought and Culture (Londra-New York: Routledge, 1992), 217.

13 Gutas, "The Poetics In Syriac And Arabic Transmission", 109; Bedevî, Fennü'ş-Şir r, 51-53.

14 Gutas, "The Poetics In Syriac And Arabic Transmission", 109. 
bir kaynağa müracaat ettiği gibi Poetika'nın Arapça tercümelerine/şerhlerine müracaaat etmiştir, eser çoğunlukla İbn Sînâ'nın Poetika'sına dayanmaktadır. ${ }^{15}$

\section{Severus Bar Şakko'nun Süryanice Fragmanında ve Mettâ B. Yûnus'un Poetika Tercümesinde Tragedyanın Tanımlanması}

Aristoteles'in tragedya tanımının en erken örneği olan Severus bar Şakko'nun (ö.

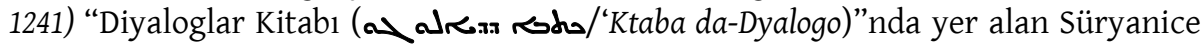
fragman; Mettâ'nın tragedya tanımını Süryaniceden Arapçaya nasıl naklettiği hakkında da bilgi veren önemli bir metindir. Nitekim Aristoteles'in metnini Mettâ üzerinden okuyan filozofların tragedyayı nasıl anladıkları ve yorumladıkları bakımından da önem arz etmektedir. Aristoteles, Severus bar Şakko ve Mettâ b. Yûnus'un tragedya tanımlarına aşağıda yer verilmektedir:

\begin{tabular}{|c|c|c|}
\hline $\begin{array}{l}\text { Aristoteles, Poetika, } \\
\text { 1449b 24-28 }\end{array}$ & 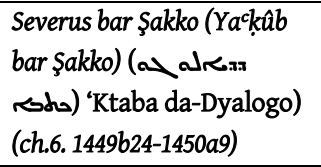 & $\begin{array}{l}\text { Mettâ b. Yûnus- Parisnus Ar. } 2346 \\
\text { (BN } 2346 \text { arabe, fol. 131a-146b) }\end{array}$ \\
\hline $\begin{array}{l}\text { Tragedya soylu, ta- } \\
\text { mamlanmış ve belirli } \\
\text { bir uzunluğu olan bir } \\
\text { eylemin taklididir. } \\
\text { Bölümlerin her birinde } \\
\text { zenginleştirilmiş bir dil } \\
\text { kullanarak yapar bunu. } \\
\text { Tragedya eyleyenleri } \\
\text { taklit eder bunu da bir } \\
\text { anlatıcıyla değil uyan- } \\
\text { dırdığı acıma ve korku } \\
\text { aracıllğı ile bu tür } \\
\text { duyguların arınmasını } \\
\text { sağlayarak yapar. }{ }^{16}\end{array}$ & $\begin{array}{l}\text { Tragedya uzunluğa sahip } \\
\text { soylu ve tamamlanmış } \\
\text { bir eylemin zevkli bir dil } \\
\text { içinde taklididir [ki] } \\
\text { parçalarındaki eylem (b) } \\
\text { türlerinden her bir türü } \\
\text { hariç/dışında ve (a) söz (c) } \\
\text { yoluyla değil fakat acıma } \\
\text { ve korku yoluyla o duygu- } \\
\text { ları yumuşatır ve (d) acı } \\
\text { çekenlerin (e) arınmasını } \\
\text { hedefler. }{ }^{17}\end{array}$ & $\begin{array}{l}\text { Medih sanatı (sinâat el-medîh); iradeye dayall (el- } \\
\text { irâdî) (f), niyetli ve tamamlanmış (el-kâmil) bir } \\
\text { eylemin (el-amel) teşbîhi ve taklididir (mu- } \\
\text { hakât); [O/tragedya] büyüklük (el-izâm) ve } \\
\text { uzunluğa (medâd) sahip olan (g), faydalı (h) bir } \\
\text { söz (el-kavl en-nâfi') içinde; bölümlerinde (el- } \\
\text { eczâ) fail olan (fâile) türlerinden (el-envâ) her } \\
\text { biri hariç/dışında (ma halâ) (i) sözler (el-mevâid) } \\
\text { (j) yoluyla değil ve acıma (er-rahmet) ve korku } \\
\text { (el-havf) yoluyla heyecanları/duyguları (el- } \\
\text { infiâlât) ve etkilenmeleri (et-te'sirât) dengeli } \\
\text { hale getirir (teaddele) ve eylemden etkilenen- } \\
\text { leri (yenféalune) arındırır/saflaştırır (tenkî) ve } \\
\text { temizler (tünezzif/tenzif). }\end{array}$ \\
\hline
\end{tabular}

15 Edzard vd., "A new look at the Greek, Syriac, and Arabic versions of Aristotle's Poetics", 224.

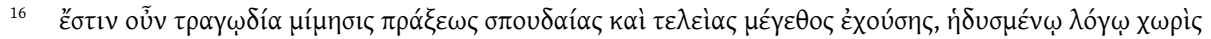

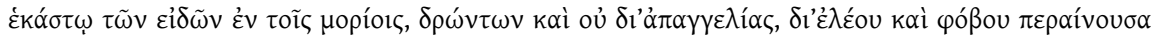

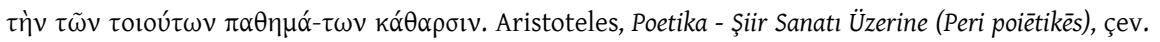
Nazile Kalaycı (Ankara: Pharmakon Kitap, 2012), 25; Rigolio, “Aristotle's Poetics in Syriac And in Arabic, Translations, 140.

17 Süryanice metin: "tragodüta" iteh meddamyanüta d-sa'örüta hpitta wa-gmirta d-it läh rabbüta bmelltä mahnyanița star men kulhad had men adše d-bamnawwata ma'bdin w-law b-yad su (w) daya 'ellä b-yad rahma w-dehltä mmazzga l-häse w-abda dukkäyä d- ilin d-hašin", Rigolio, "Aristotle's Poetics", 140; Edzard vd., "A new look at the Greek, Syriac, and Arabic versions of Aristotle's Poetics", 231. 
Günümüze ulaşan Süryanice paragrafdaki tragedya tanımı ile Aristoteles'in tanımı örtüşmemektedir. Severus bar Şakko'nun yukarıda alıntılanan paragrafında “italik ve harfler" ile gösterilen kelimeleri farklı şekillerde tercüme imkânı olmasına rağmen Süryani mütercim, Aristoteles'in metninin içeriğini tam olarak yansitmamıştır. Özellikle hariç/dışında (a) ve söz (c) kelimelerinin tercümesi Yunanca elyazmasındaki olası içeriğini taşımaması, sonrasında Mettâ b. Yûnus'un metni doğru anlamasına engel teşkil etmiştir. Süryanice mütercim Yunan sanatlarını ve tragedyayı bilmemesi nedeniyle; Aristoteles'in Poetika'sinda yer alan "tragedya eyleyenleri taklit eder" ifadesindeki vurgunun eyleyenlere yani aktörlere atıf yaptı̆̆ını gözden kaçırmıştır. Süryani mütercim eyleyen/eylemde bulunan insanlara yani oyuncu (aktör) atıf yaparak tercüme etmek yerine Aristoteles'in metninde geçen kelimeyi "eylem türleri" (b) olarak yorumlamıştır. ${ }^{19}$ Bu tür eksik ve yanlış tercüme ile tragedyanın teatral özelliklerinin ifade edilmemiş ve yanlış tercüme Poetika'nın sonraki nakillerinde ve yanlış anlaşılması üzerinde büyük bir etkiye sahip olmuştur. $^{20}$

Süryanice metinde yer verilen "duyguları yumuşatır ve (d) acı çekenlerin (e) arınmasını hedefler" ifadeleri katharsis kavramını genişletmek için mütercimin çabasının açık bir şahidi olarak yorumlanmıştır. O duyguları yumuşatır ve (d) ifadesi Süryanice bir ekleme gibi görünmektedir. Acl çekenlerin (e) ifadesi ise Yunanca metinden radikal bir değişikliktir. Belki de katharsisin farklı bir yorumunun altında yatan asıl sebebi ima etmektedir. Belki de Yunanca "bu tür duygular" ( $\tau \tilde{\omega} v$

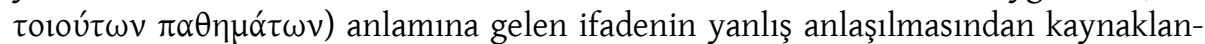

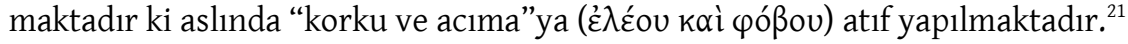

Severus bar Şakko'nun Süryanice paragrafındaki kimi kelimeleri Mettâ, çift kelime ile tercüme etmiştir. Nitekim tek bir kelime/kavramı çift kelime ile tercüme etmek Mettâ'nın en önemli tercüme tekniği ya da üslupsal özelliği olarak nitelenmiştir. Süryanice metninde yer alan mimesis (taklit) teriminin karşılığı iki tamamlayıc1 ve eş anlamlı terim ile yani "muhâkât ve teşbih" ile karşılanmıştır. Mettâ'nın Arapça tercümesindeki en önemli değişiklik tragedyayı "medih sanatı (sinâat elmedîh)" olarak çevirmesidir. Mettâ tragedyaya ( $\tau \rho \alpha \gamma \omega \delta i ́ \alpha)$ medih (el-medîh), komedyaya $(\kappa \omega \mu \omega \delta i ́ \alpha)$ ise hiciv (el-hicâ) karşılıklarını vererek bu iki terimi tüm metninde tutarlı bir şekilde kullanmıştır. ${ }^{22}$ Bu seçim özellikle problematiktir çünkü söz konusu Yunanca iki terim Süryanicede nadir kullanılan terimler değildir. Mettâ

\footnotetext{
18 Ayyâd, Kitâbu Aristotâlis fiş-Şi’r, 49; Bedevî, Fennü’ş-Şirr, 96; Rigolio, “Aristotle’s Poetics”, 142.

19 Rigolio, “Aristotle's Poetics", 141.

20 Rigolio, "Aristotle's Poetics”, 146.

21 Rigolio, "Aristotle's Poetics", 146.

22 Michiel Leezenberg, "Katharsis, Greek And Arab Style, On Averroes's Misunderstanding of Aristotle's Misunderstanding of Tragedy", Rereading Classics in 'East' and 'West' Post-colonial Perspectives on the Tragic, ed. Freddy Decreus-Mieke Kolk (Gent: Documentatiecentrum voor Dramatische Kunst Gent, 2004), 304.
} 
Süryanicedeki karşılığ1 "țrāgodūtā" ve "qūmōdiy $\bar{a}$ ” olan kelimeler ile kastedilen şeyin tam olarak ne olduğunu konusunda tahminde bulunmuş ve farklı bir strateji ile bu iki kelimeyi Arap edebiyatındaki bir forma adapte etmiştir. ${ }^{23}$ Mettâ tercümesinde Yunan dünyasındaki pek çok özel isim ve Yunan sanatlarını transliterasyon ile vermiştir. Örneğin epik şiiri/epos "fen/sanat/sınaât efi” olarak yani transliterasyon ile vermiştir. Tragedya ve komedya Yunanca kelimeleri transliterasyon ile verme imkânı varken bunu tercih etmemiştir. Mettâ bu iki kelimenin tercümesini, Arap edebiyatındaki iki tür üzerinden kendi anlayışına dayanarak tercüme etmiştir;

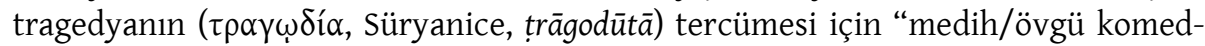

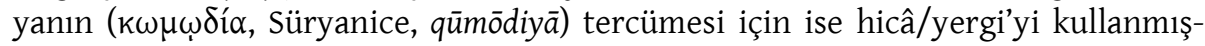
tir. $^{24}$

Arap edebiyatında ya da kaside geleneğinden övgü şiiri ya da medih için genellikle medh, medîh, medîha, ümdûha ve midha kelimeleri kullanılmaktadır. Yergi/hiciv karşılığında hicâ terimi kullanılmakta, hiciv türü şiire ühcüvve, ühciyye (ç. ehâcî) karşılı̆̆ı verilmektedir. Medih şiiri bireylere, ailelere, kabilelere övgüyü ifade etmekte $^{25}$ kişisel ve ahlakî özellikler/erdemler (cömertlik, asalet, dürüstlük, vefakârlık, kahramanlık gibi) övülmektedir. Hiciv ise bu özelliklerin zıdlarını içermektedir. $^{26}$

Mettâ b. Yûnus, tragedyayı medih/övgü şiiri, komedyayı da hica/yergi şiiri olarak tercüme etmeye karar verirken, Kindî zamanından beri Aristotelyen metinlerle uğraşan Arap entelektüelleri arasında tesis edilmiş bir geleneği takip etmiştir. ${ }^{27}$ Nitekim Kindî Aristoteles'in Kitaplarının Sayısı Üzerine adlı risalesinde Retorika ve Poetika'yı övgü ve yergi terimleri üzerinden açıklamıştır: "Şiirle ilgili demek olan Poeti$k a$ adlı sekizinci kitabındaki amacı şiir sanatından söz etmekte övgü, ağıt, hiciv ve daha başka şiir türlerinde kullanılan vezinleri anlatmaktadır." ${ }^{28}$ Mettâ b. Yûnus'un Yunan dünyasına ait kimi konuları Arapça şiir türleriyle tanıtan Kindî geleneğini takip ettiğini söylemek mümkündür. Nitekim bu tercihin asıl amacı, Yunan kültürünün Arapça konuşan topluma intibakını sağlamaktır. Buna karşıt farklı bir süreç önce Fârâbî tarafından ve ardından onu takip eden İbn Sînâ tarafından işletilmiştir.

23 Rigolio, “Aristotle's Poetics”, 143.

24 Edzard vd., "A new look at the Greek, Syriac, and Arabic versions of Aristotle's Poetics, 229; Rigolio, “Aristotle's Poetics", 140.

25 İsmail Durmuş, "Methiye”, TDV İslam Ansiklopedisi (İstanbul: Türkiye Diyanet Vakfı Yayınları, 2004), 29/406-408; Hüseyin Elmalı, “Kaside”, TDV İslam Ansiklopedisi (İstanbul: Türkiye Diyanet Vakfı Yayınlar1, 2001), 24/562-564.

26 M. Orhan Okay, "Hiciv”, TDV İslam Ansiklopedisi (İstanbul: Türkiye Diyanet Vakfı Yayınları, 1998), 17/449-450; İsmail Durmuş, "Hiciv”, TDV İslam Ansiklopedisi (İstanbul: Türkiye Diyanet Vakfı Yayınlar1, 1998 ), 17/447-449.

27 Dimitri Gutas, “On Translating Averroes' Commentaries Averroes' Middle Commentary on Aristotle's Poetics”, Journal of the American Oriental Society 110/1 (1990), 92.

28 Mahmut Kaya, Kindî: Felsefî Risaleler (İstanbul: Klasik Yayınları, 2002), 274. 
İbn Sînâ mümkün olduğu kadar tarafsız olma çabasıyla, Arapça'da yeterli karşıllı̆̆1 bulunmayan ya da bilinmeyen türlerin adlarını transliterasyonu ile vermekte, mümkün olduğu kadar Aristoteles'in metnine sadık kalmaya gayret etmektedir. İbn Rüşd'ün ise Mettâ ve Kindîyi takip etmesi filozofun temel yaklaşımını göstermesi bakımından önemlidir. ${ }^{29}$

Aristoteles'in Poetika'sındaki kimi paragraflarında bu iki kelimenin Mettâ b. Yûnus'un tercümesine mutabık bazı dayanakları da bulunabilmektedir. Dolayısıyla tragedyaya medih, komedyaya da hiciv karşıllı̆ını vermek bütünüyle yanlış ve yersiz değildir. Aristoteles' in Poetika'sının "1448a 16-18" ve "1448b 20-27" paragrafları tragedyanın medih, komedya da hiciv olarak yorumlama imkânı sunmaktadır. ${ }^{30}$

Mettâ b. Yûnus'un medih sanatını, iradeye dayalı (el-irâdî)(f) olarak tanımlamış olması da Aristoteles'in tragedya tanımına dayanmamaktadır. İrâdî kelimesinin tercümeye dâhil edilmesinin kökleri belki de bir eylemin ancak maksatlı olarak irade ile ya da seçim ile yapıldığı takdirde övgüye değer olabileceği yönündeki ahlakî düşünceden kaynaklanması mümkündür. Muhtemelen Nikohamas Etik'te (1109b30-1115a3) ifade edilen Aristoteles kökenli bir okuma olarak değerlendirilmektedir. ${ }^{31}$

Mettâ tragedyanın büyüklük (el-izâm) ve uzunluğa (medâd) sahip olduğunu (g) ifade etmektedir. Bu ifade (g) Yunancadan farklı olarak Süryanicedeki belirsizliğinin bir sonucu olarak hem tragedya'nın [țrāgodūtā] hem de "eylemin" [sātôrūtā] dişil/müennes terimler olması ve Mettâ'nın yanlış bir şekilde büyüklük (el-izâm) ve uzunluğu (medâd), eylemden çok tragedyaya atfetmesi ile sonuçlanmıştır. ${ }^{32}$

Tercümedeki diğer bir farklılık faydall ( $h$ ) bir söz (el-kavl en-nâfi') ifadesinde geçen faydal//en-nâfi' (h) kelimesidir. Süryanice metinde yer alan "mahnyānitā" kelimesi hem "hoş" hem de "yararlı" anlamına gelmektedir. Mettâ söz konusu kelimeyi faydall/en-nâfi olarak tercüme etmiştir.

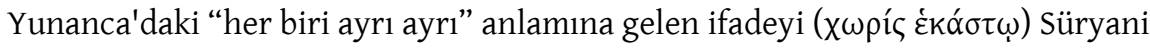
tercüman "her biri hariç/dışında" şeklinde tercüme etmişs ${ }^{33}$ Mettâ b. Yûnus da hariç/dışında (ma halâ) (i) kelimesi ile Arapçaya nakletmiştir. ${ }^{34}$

Metinde yer alan "söz (el-mevâid) (j)" kelimesi Süryanice metnin aksine, Arapça

29 Gutas, “On Translating Averroes' Commentaries Averroes' Middle Commentary on Aristotle's Poetics", 95.

30 Rigolio, "Aristotle's Poetics", 143, 144.

31 Rigolio, "Aristotle's Poetics", 143, 14; Dahiyat, Avicenna's Commentary on the Poetics of Aristotle, 88.

32 Edzard vd., "A new look at the Greek, Syriac, and Arabic versions of Aristotle's Poetics”, 233.

33 Gutas, "On Translating Averroes' Commentaries Averroes' Middle Commentary on Aristotle's Poetics", 95.

34 Gutas, "On Translating Averroes' Commentaries Averroes' Middle Commentary on Aristotle's Poetics", 95. 
çoğul bir kelimedir (mev`ld/ç. mevâiid). Süryanice tercüman, bu kelimenin tercümesinde ifadeyi anlaşılmaz kılan bir hata yapmıștır. Apaggelia (anlatım, anlatı) ve epaggelia'yı (söz) iki farklı kelimedir. Söz (el-mevâid) (j) kelimesi, Yunanca epaggelia kelimesinin çoğul formunun literal bir tercümesidir. Bu bağlamda epaggelia kelimesi, uygun kelime olan apaggelia ile yani "ezberden okuma, hikâye etme, haber verme, anlatım” kelimesi ile karıştırılmıştır. Birinci hata Süryani mütercimler tarafından, sonuncusu ise Ebu Bişr Mettâ tarafından yapılmıştır. Böylelikle tragedyanın dramatik modunu vurgulayan Aristoteles’in cümlesi bütünüyle gizlenmiștir.

\section{Mettâ b. Yûnus, İbn Sînâ ve İbn Rüşd'de Tragedya ve Medih Sanatı}

İbn Sînâ erken bir tarihte kaleme aldı̆̆ı el-Hikmet'ül-Arûziyye'de ${ }^{35}$ ve Poetika'nın (Fennü'ş-Şír min Kitâbi'ş-Şifâ) ilk bölümünde farklı Yunan sanatlarını ve tragedya tanımlamakta ve Fârâbî̀nin Şiir Sanatının/Şairlerin Sanatının Kanunları Hakkında Risale metninden aynen nakletmiştir. İbn Sînâ'nın Mettâ'nın metnini değil de Yahyâ b. Adî̀nin tercümelerini esas almasın sebebiyle, tragedyayı medih sanatı olarak değil transliterasyon ile vermektedir. İbn Rüşd tragedya'yı Mettâ'nın metnini takip ederek "medih sanatı" olarak tercüme etmiştir. Nitekim İbn Rüşd'ün metninin bütünü dikkate alındığı takdirde filozofun konuyu ele alış biçiminin Aristoteles’ten farklıl1ğı ve konuyu özellikle Arap şiirleri ve Ku'ran ayetleri üzerinden açıkladığı görülecektir. Bu bağlamda filozofun açıklamaları bir Yunan sanatı olan tragedya üzerinden değil Arap edebiyatının bir formu olan medih üzerinden anlatılmaktadır. Mettâ b. Yûnus, İbn Sînâ, İbn Rüşd’ün tragedya ve medih tanımları aşağıda yer almaktadir.

\begin{tabular}{|c|c|c|}
\hline Mettâ b. Yûnus & İbn Sînâ & İbn Rüşd \\
\hline Medih sanatı & Tragedya & Medih sanat1 \\
\hline $\begin{array}{l}\text { Medih sanatı (stnâat el-medîh); iradeye } \\
\text { dayalı (el-irâdî) (f), niyetli (el-harîs) ve } \\
\text { tamamlanmış/mükemmel (el-kâmil) } \\
\text { bir eylemin (el-amel) teşbîhi ve } \\
\text { taklididir (muhakât), [O/tragedya] } \\
\text { büyüklük (el-izâm) ve uzunluğa (medâd) } \\
\text { sahip olan (g), faydall (h) bir söz (el-kavl } \\
\text { en-nâfi') içinde, bölümlerinde (el-eczâ) } \\
\text { fail olan (fâile) türlerinden (el-envâ) } \\
\text { her biri hariç/dışında (ma halâ) (i) } \\
\text { sözler (el-mevâid) (j) yoluyla değil ve } \\
\text { acıma (er-rahmet) ve korku (el-havf) } \\
\text { yoluyla heyecanları/duyguları (el- } \\
\text { infiâlât) ve etkilenmeleri (et-te'sirât) }\end{array}$ & $\begin{array}{l}\text { Tragedyayı tanımlamamız } \\
\text { gerekirse şöyle deriz: } \\
\text { Tragedya, tam/mükemmel, } \\
\text { faziletli (kâmil el-fazilet) (k) } \\
\text { ve mertebece yüksek } \\
\text { (âliyil-mertebeti) bir fiilin; } \\
\text { tek tek cüz'î bir fazilete (l) } \\
\text { tahsis edilmeksizin, tam } \\
\text { uygun bir dil kullanılarak } \\
\text { taklididir; [ki] tikeller (el- } \\
\text { cüziyyât) (m) meleke ( } n \text { ) } \\
\text { bakımından değil fakat fiil } \\
\text { bakımından etkiler, taklit } \\
\text { etmek (muhâkât), ruhu }\end{array}$ & $\begin{array}{l}\text { Medih sanatının özünü } \\
\text { anlamayı sağlayan tanım; } \\
\text { iradeye dayal faziletli (el-fâzıl) } \\
\text { ve tam/mükemmel (el-kâmil) } \\
\text { eylemin teşbihi ve taklididir, } \\
\text { faziletli şeyler küllî bir kuvve- } \\
\text { te sahiptir, faziletli durumla- } \\
\text { rın her biri, cüzî bir kuvvete } \\
\text { sahip değildir. Taklit; acıma } \\
\text { (rahmet) ve korku (havf) } \\
\text { yoluyla ortaya çıkan şeylerle } \\
\text { ruhlara mutedil bir şekilde } \\
\text { etki eder. Bu, faziletli kişiler- } \\
\text { de saflık (nikâ) ve arınmanın/ }\end{array}$ \\
\hline
\end{tabular}

35 İbn Sînâ, Kitabu'l-Mecmû ev el-Hikmet'ül-Arûziyye, nşr. Muhsin Salih (Beyrut: Daru'l-Hâdi, 2007), 105110. 


\begin{tabular}{|l|l|l|}
\hline $\begin{array}{l}\text { dengeli hale getirir (teaddele) ve } \\
\text { eylemden etkilenenleri (yenfe'alune) }\end{array}$ & $\begin{array}{l}\text { (nefs) acıma (rahmet) ve } \\
\text { korkuya (takva) doğru }\end{array}$ & temizlenmenin (nezâfet) \\
hayal edilmesi ile olur. ${ }^{38}$ \\
ler (tünezzif/tenzif). ${ }^{36}$
\end{tabular}

Mettâ'nın metninde yer alan “büyüklük (el-izâm) ve uzunluğa (medâd) sahip olan (g)" cümlesi hem İbn Sînâ'nın metninde hem de İbn Rüşd'ün metninde tamamen atlanmıştır.

İbn Sînâ'nın tragedya tanımında eylemi niteleyen "kâmil el-fazîlet" ( $k$ ) ifadesinin literal anlamı "tam/mükemmel/yetkin fazilet" (ya/ya da "fazileti tam/yetkin) tir. "Tam/yetkin faziletler" olarak ifade edilen eylemin Aristoteles’teki karşılı̆̆ı, "seçime dayanan/iradî eylemlerdir". Fazilet teriminin mânâsı, İbn Sînâ'nın farklı bir paragrafına müracaat edilerek belirlenebilmektedir. ${ }^{39}$ Poetika IV/15'de İbn Sînâ "fazileti ahlakî bir nitelik olarak" açıklamaktadır. Bir eylemin tam faziletli olabilmesi için, 'irade ile seçilmiş', 'soylu' ve 'tam' olması zorunludur. Nitekim İbn Sînâ, Mettâ'nın tragedya tanımını da biliyordu, buna göre "tam/yetkin fazilet” ifadesi, Mettâ'nın "iradeye dayalı (el-irâdî) (f), niyetli ve tamamlanmış/mükemmel (el-kâmil)" cümlesinin farklı bir formda ifadesi olabilir. İbn Rüşd, Mettâ'nın metninde de yer alan "iradeye dayalı faziletli (el-fâzıl) ve tam/mükemmel (el-kâmil) (o)" ifadesini almış bunun yanı sıra İbn Sînâ'nın metnine eklediği fazilet ( $k$ ) kelimesini de kullanmıştır. ${ }^{40}$ İbn Rüşd, Mettâ'nın mimesis karşılığı olarak verdiği iki kelimeyi de “teşbih ve takliti (muhâkât)" aynen kullanmıştır.

İbn Sînâ tragedyanın, tam/mükemmel, faziletli (kâmil el-fazilet) bir fiilin taklidi olup tek tek cüzî̀ bir fazilete (l) tahsis edilemeyeceğini ifade etmektedir. İbn Rüşd, İbn Sînâ'nın bu yorumunu alır ve bunu daha açıklayıcı bir şekilde genişletir. Buna göre "faziletli şeyler küllî bir kuvvete sahiptir, faziletli durumların her biri, cüzî bir kuvvete sahip değildir” şeklinde ifade eder. İbn Rüşd, İbn Sînâ'yı takip ederek (ve dolaylı olarak, Fârâbî ve onun kaynaklarının arkasındaki Yunan Aristoteles geleneğini), övgü şiirini, her bir fazilet/erdem hakkında değil, küllî faziletler hakkında olduğunu ifade eder.

36 Ayyâd, Kitâbu Aristotâlis fiş-Şi'r, 49; Bedevî, Fennü'ş-Şiłr, 96; Rigolio, “Aristotle’s Poetics”, 142.

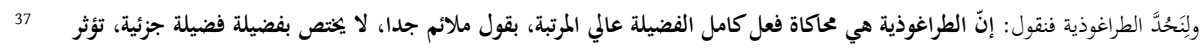

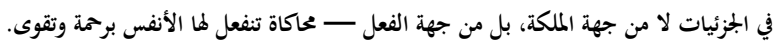

İbn Sînâ, “Fennü’ş-Şi'r r”, Fennü’ş-Şiłr nşr. Abdurrahman Bedevî (Beyrut: Dâru's-sakafe, 1953), 170.

والحد المفهم جوهر صناعة المديح هو أها تشبيه ومحاكاة للعمل الإرادى الفاضل الكامل الذي له قوة كلية في الأمور الفاضلة، لا قوة جزئية في 38 في 3

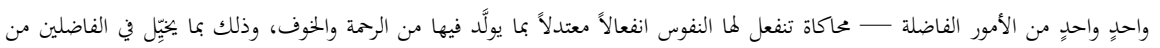
النقاء والنظافة

İbn Rüşd, “Telhîsu Kitâbi Aristûtâlîs fi'ş-Şi'r", Fennü’ş-Şi rr, nşr. Abdurrahman Bedevî, 231.

39 Dahiyat, Avicenna's Commentary on the Poetics of Aristotle, 88.

40 Dahiyat, Avicenna's Commentary on the Poetics of Aristotle, 88. 
İbn Sina'nın tragedya tanımında yer alan Arapça “el-cüziyyât”(tikel) (m) kelimesi İbn Sînâ'nın felsefi terminolojisinde külliyâtın (tümel) karşıtıdır. Bu bağlamda İbn Sînâ'nın bireyler mânâsını kastetmiş olabileceği ifade edilmektedir. ${ }^{41}$ Poetika'nın farklı bir paragrafında İbn Sînâ benzer bir kelimeyi şu şekilde kullanmıştır: "Tek bir tikel/kişi (li-vâhid el-cüziyye) için sınırsız cüzi/tikel eylem (ef'âl el-cüziyye) vardır." Dahiyat, cüziyyatın bireylere/kişilere yani taklit eden ya da taklit edilen şeylere atıf yaptığının açık olduğunu ifade etmektedir. ${ }^{42}$ Eğer cüziyyat kelimesi, taklit eden kişilere atıf yapıyorsa, cümlenin devamı (melekeler bakımından değil eylemler bakımındandır) şu şekilde yorumlanabilir: Taklit eden kişiler, taklit edilen şeylerin ahlakî niteliklerini doğrudan söylemez, onlar taklit edilen şeylerin ahlakî özelliğini açı̆̆a çıkartan bir eylem tarzını canlandırır. İbn Sînâ bireyler ile 'taklit edilen şeylere' atıf yapmayı düşünmüş olabilir. Bu bağlamda filozof tragedyadaki temsil tarzı hakkında konuşmuyor olabilir. Çünkü tragedya dramatiktir, anlatıya dayalı değildir. Bu sebeple tragedyada taklidin objesi eylemlerdir, melekeler değildir.

İbn Sînâ, Mettâ'nın metninde yer alan "bölümlerinde (el-eczâ) fail olan (fâile) türlerinden (el-envâ) her biri hariç/dışında (ma halâ)" cümlesindeki fail olan (fâile) kelimesi (tercümedeki faile kelimesinin eyleyen insanların eylemlerine atıf yaptı̆̆ varsayılabilir) tragedyanın tikellere (cüziyyât) atıf yaptığını düşünmüş ve Mettâ'nın metnindeki sözler (el-mevâid-epaggelia) kelimesi ve (anlatımın yerine Yunanca apaggelia) kelimesini karakterin özelliği manası ile "meleke" şeklinde yanlış tercüme etmiştir. ${ }^{43}$ İbn Rüşd'ün medih tanımında bu cümleler atlanarak tragedyanın korku ve acıma gibi duygusal etkilerine geçilmiştir.

Mettâ, Aristoteles'in katharsis (arınma) ile ilgili ifadelerini şu şekilde yorumlamiştır: "Acıma (er-rahmet) ve korku (el-havf) yoluyla heyecanları/duyguları (elinfiâlât) ve etkilenmeleri (et-te'sirât) dengeli hale getirir (teaddele) ve eylemden etkilenenleri (yenfecalune) arındırır/saflaştırır (tenkî) ve temizler (tünezzif/tenzif)." ${ }^{44}$ Mettâ'nın bu çevirisi Aristotelesçi katharsis kavramının belirsizliğini yeniden üretmekle kalmaz, aynı zamanda katharsisin farklı bir şekilde yorumlanması, kavramın olası açıklanmalarına dair daha fazla imkân sunar. Yunanca orijnal metindeki katharsisin duygusal etkilerine ya da tıbbî veya psikolojik açıklamalarına Mettâ'nın çevirisi yeni bir ahlakî özellik eklemektedir. Arapça metindeki ifade çok açık değildir. Bu belirsizliğin kaynağı, "harekete geçmek”, "yapmak", "eylemek” anlamına gelen "fiil" kelimesinin aynı kökten gelen pasif formunun (eylemden etkilenenleri (yenfeılûne)) kullanılmasıdır. "Eylemden etkilenlerin" öznesinin kim veya ne olduğu örtük ve belirsizdir. Heyecanlardan/ duygulardan (el-infiâlât) ve etkilenmelerden (et-te'sirât) bahseden dolaysız bağlam göz önüne alındığında, “arındırılanların şiir-

41 Dahiyat, Avicenna's Commentary on the Poetics of Aristotle, 89.

42 Dahiyat, Avicenna's Commentary on the Poetics of Aristotle, 89.

43 Gutas, “On Translating Averroes' Commentaries Averroes' Middle Commentary on Aristotle's Poetics”, 95.

44 Ayyâd, Kitâbu Aristotâlis fiş-Şi’r, 49; Bedevî, Fennü’ş-Şiłr, 96; Rigolio, “Aristotle’s Poetics”, 142. 
sel ifadenin dinleyicileri” olduğu söylenebilir. ${ }^{45}$ Bununla birlikte, eylemin etkisinde kalanların (yenfeilûne/yuf'alûne), metindeki karakterlerin taklit ettiği eylemlerden (efâl) etkilenen kişilere atıfta bulunduğu şeklinde okumak da mümkündür. Bir tragedya ya da bir övgü şiiri dinleyicinin/izleyicinin duygu ve izlenimlerini içerebilir; fakat aynı zamanda temsil edilen karakterleri de içerebilirler. Yunanca orijinalinden okuma imkânı olanlar için, ikinci okuma biçimi son derece mantıksızdır; ancak Yunanca metnin orijinaline ulaşım imkânı olmayan Süryani mütercimler ya da filozoflar için olası bir okumadır. Nitekim İbn Rüşd'ün yorumunda benzer bir belirsizlik olduğu görülecektir. ${ }^{46}$

İbn Sînâ tragedyanın duygusal etkilerine değinmektedir: "Taklit etmek (muhâkât), ruhu (nefs) acıma (rahmet) ve korkuya (takva) doğru harekete geçirir(e)" ifadesinde tragedyanın kathartik yönleri dikkate alınmamış, katharsise doğrudan atıf yapılmamıștır. Bunun sebebi İbn Sînâ'nın Yahya b. Adi'nin metnini kullanması olabilir. İki trajik duygu yani "acıma ve korku"; rahmet ve takva kelimeleriyle açıklanmıştır. Metnin farklı paragraflarında "şefkat (rikkat) ve korku (takiyye)" ya da "şefkat (rikkat), hüzn ve korku (takiyye)" ifadeleri ile tragedyanın duygusal etkileri açıklanmıştır. ${ }^{47}$ Takva kelimesine 'saygıdan kaynaklanan korku' ya da 'hürmetten kaynaklanan korku' anlamları verilebilir ki kelimenin yaygın karşıllğı 'Allah korkusu'dur.

Katharsise dair yorumlar İbn Sînâ ve İbn Rüşd'ün metinlerinde farklllık göstermektedir. Yukarıda da ifade edildiği gibi bunun sebebi iki filozofun farklı çevirileri esas almaları olabilir. Nitekim İbn Rüşd tragedya yerine medih terimini kullanmış ve Mettâ'nın terminolojisini yeniden üretmiş görünmektedir. Katharsis hakkındaki açıklamalarda da İbn Rüşd, Mettâ’nın metnine geri dönmektedir: "Taklit; acıma (rahmet) ve korku (havf) yoluyla ortaya çıkan şeylerle ruhlara mutedil bir şekilde etki eder. Bu, faziletli kişilerde saflık (nikâ) ve arınmanın/temizlenmenin (nezâfet) hayal edilmesi ile olur". Metinde ifade edilen durum saflı ve arınmanın; izleyicinin veya işitenin ruhunun arınmasının bir sonucu değil, daha çok metinde temsil edilen karakterlerin saflığı veya arınması ile ilişkilendirilmiş görünmektedir. İbn Rüşd'ün yorumu, Mettâ'nın çevirisinde kullandığı pasif fiilin (yuf'alûne) yukarıda ifade edilen belirsizliğini yansıtmaktadır.

Aristoteles'in dilbilimsel, tıbbî ya da psikolojik uzantıları ile açıklanan katharsis hakkındaki açıklamalarına karşın klasik İslam geleneğinde katharsis çok daha az önemli bir role sahiptir. Tragedyanın tanımlarında katharsisin psikolojik ve duygusal etkilerine vurgu yapılmaması, şiirsel ifadelerin ya da farklı formların amacının sadece zevk vermek değil, dinleyicileri ikna etmek olduğu şeklindeki daha genel bir bağlama müracaat etmekle açıklamak mümkündür. ${ }^{48}$ Sonuç olarak Aristoteles'in

\footnotetext{
45 Leezenberg, "Katharsis, Greek And Arab Style”, 304-307.

46 Leezenberg, "Katharsis, Greek And Arab Style”, 307.

47 Taşkent, İbn Sînâ ve Fârâbînin Poetikaları, 110.

48 Leezenberg, "Katharsis, Greek And Arab Style", 306.
} 
katharsis düşüncesi İbn Sînâ ve İbn Rüşd'ün yorumlarında merkezi bir rol oynamamıştır. Bunun sebebini "tragedyanın farklı bir kültüre ait sanatsal bir formu olduğundan yeterince anlayamamak ya da Yunan tragedyasına olan ilgisizlik ile açıklamak yeterli bir açıklama gibi görünmemektedir. Bunun sebebi İslam geleneğindeki Poetika'nın alımlanışı ile ilgili sürece müracaat etmekle yani "bağlam teorisi” olarak adlandırılan, Retorik ve Poetika'nın, mantı̆̆ın parçaları olarak görülmesi ile ilişkilendirmek gerekmektedir. ${ }^{49}$ Aristoteles'in mantıkla ilgili yazdı̆̆ 1 altı kitap; Kategoriler (Katêgoriai: Kitâbu'l-Mekûlât), Yorum Üzerine (Peri Hermêneias: Kitâbu'l'İbâre), Birinci Analitikler (Analütika Protera: Kitâbu'l-Kıyâs), İkinci Analitikler (Analütika Hüstera: Kitâbu'l-Burhân), Topikler (Topika: Kitâbu'l-Cedel), Sofistik Çürütmeler Üzerine (Peri Sophistikôn Elenkhôn: Kitâbu'l-Mugâlata) Bizanslılar döneminde "âlet" anlamina gelen Organon adı altında bir araya getirilmiştir. Yeni-Platoncular ve Süryaniler tarafından Aristoteles'in Retorik (Tekhnês Rhêtorikes: Kitâbu'l-Hatâbe) ve Poetika (Peri Poiêtikês: Kitâbu'ş-Şi'r) adlı eserleri Organon'a ilave edilmek suretiyle mantık kitaplarının sayısı sekize çıkarılmıştır. Porphyrius'un (ö. 305), Aristoteles’in “kategorilere giriş” olarak, onları izah maksadıyla yazdığı İsagoci'sinin (Eisagôgê) ilavesiyle Mantık külliyatını oluşturan kitapların sayısı dokuza çıkarılmıştır. İslam filozoflarının Poetika'yı mantık içinde değerlendirmesinin en önemli sebebi, eserin yukarıda ifade edilen tarihî süreç içerisinde Organon külliyatı içine dâhil edilmesinden kaynaklanmaktadır. Bu her ne kadar Aristoteles'ten farklı olarak daha sonraki Grek yorumcuların verdiği Poetika bağlamı olsa da, İslam felsefesinde Poetika çalışmaları mantık biliminin içinde değerlendirilerek eserin orjinalinde olmayan Arapça yazımın "mantıkî" rengini almıştır. ${ }^{50}$

\section{Tragedya ve Medhin Nitel Analizi}

Aristoteles'in Poetikasında yer verilen tragedyanın altı öğesi; muthos, ethos, leksis, dionoia, opsis, harmonia/melopoiia; Mettâ b. Yûnus, İbn Sînâ ve İbn Rüşd'ün eserlerinde yer yer birbirine yakın zaman zaman da farklılaşan terimler ile ifade edilmiştir.

\begin{tabular}{|l|l|l|l|l|}
\hline & Aristoteles & Mettâ b. Yûnus & İbn Sînâ & İbn Rüşd \\
\hline & TRAGEDYA & MEDíH & TRAGEDYA & MEDİH \\
\hline 1 & Muthos/mythos (öykü) & $\begin{array}{l}\text { Öykü } \\
\text { (el-hurâfe/el- } \\
\text { hurâfât })\end{array}$ & $\begin{array}{l}\text { Öykü/hurâfe, kurgusal şiir- } \\
\text { sel sözler (ekavil şi'riyye ve'- } \\
\text { hurâfiyye) }\end{array}$ & $\begin{array}{l}\text { Öykü/hurâfe, öykü } \\
\text { içeren kaviller (el- } \\
\text { ekâvîl hurâfiyye) }\end{array}$ \\
\hline
\end{tabular}

49 Poetika ve Mantık arasındaki ilişki hakkında bkz. Deborah L. Black, Logic and Aristotle's Rhetoric and Poetics in Mediavel Arabic Philosophy (Leiden: E.J. Brill, 1990).

50 Black, Logic and Aristotle's Rhetoric and Poetics in Mediavel Arabic Philosophy, 52-102; Dimitri Gutas, Greek Philosophers in the Arabic Tradition (Aldershot-Burlington: Ashgate Variorum, 2000), 44; Geert Jan Van Gelder, Takhyil: The Imaginary in Classical Arabic Poetics (Great Britain: Gibb Memorial Trust, 2007), 2-5. 


\begin{tabular}{|c|c|c|c|c|}
\hline 2 & Ethos (karakter) & $\begin{array}{l}\text { Adetler } \\
\text { (el-âdât) }\end{array}$ & $\begin{array}{l}\text { Âdetler yoluyla kendisine } \\
\text { teşvik edilen mânâlar (el- } \\
\text { meânî elleti ceret el-adet bi'l } \\
\text { hasse aleyha) }\end{array}$ & $\begin{array}{l}\text { Adetler/karakterler } \\
\text { (el-âdât) }\end{array}$ \\
\hline 3 & $\begin{array}{l}\text { Leksis (sözel ifade) } \\
\text { Metron/ölçü }\end{array}$ & $\begin{array}{l}\text { Söz } \\
\text { (el-mekûle) }\end{array}$ & Ölçü (el-mukâbele; el-vezn) & Ölçü (el-vezn) \\
\hline 4 & Dianoia/düşünce & $\begin{array}{l}\text { İnanç } \\
\text { (el-itikad) }\end{array}$ & $\begin{array}{l}\text { Hüküm ve düşünce/görüş } \\
\text { (el-hüküm ve'r-re'y) }\end{array}$ & İnançlar (itikad) \\
\hline 5 & Opsis/sahne düzeni & $\begin{array}{l}\text { Görülen yer } \\
\text { (el-manzar) }\end{array}$ & $\begin{array}{l}\text { Nazar (bakış/görünüş) } \\
\text { Araştırma ve nazar (el-bahs } \\
\text { ve'n-nazâr) nazar ve delil } \\
\text { getirme (nazar ve ihticac) }\end{array}$ & $\begin{array}{l}\text { (en-nazar) } \\
\text { nazar ve ihticac } \\
\text { (delil getirme) }\end{array}$ \\
\hline 6 & $\begin{array}{l}\text { Harmonia/harmoni } \\
\text { (melopoiia/ezgi düz- } \\
\text { me) }\end{array}$ & $\begin{array}{l}\text { Nağme } \\
(\text { en-nağme) } \\
(\text { es-savt })^{51}\end{array}$ & Melodi (lahn) & Melodi (lahn) \\
\hline
\end{tabular}

\section{1. Öykü (el-hurâfe/el-hurâfât)}

Mettta b. Yûnus da "öyküler (el-hurâfât)", İbn Sînâ da "öykü/hurâfe ve kurgusal şiirsel sözler” (ekavîl şi'riyye ve'l-hurâfiyye) ve İbn Rüşd de "öykü içeren kaviller” (elekâvîl hurâfiyye) şeklinde ifade edilen hurâfe/öykü; Aristoteles'in muthos/mythos ( $\mu$ Эos)' olarak adlandırdığı şeyi açıklayan bir kelimedir. Mūthos/myth "söylence, mit, söz, nutuk, esâtir, hikâye, laf, anlatma, masal, öğüt, fabl, söylence, öykü” anlamına gelmektedir. ${ }^{52}$ Aristoteles Poetika'da (1450a 3-5) muthos'u şöyle tanımlamaktadır: "Eylemin taklidi ise öyküdür: Öykü'den olayların biraraya getirilmesini anl1yorum." Aristoteles tragedyanın temel parçası olarak öyküyü "eylemin taklidi" olarak açıklamaktadır. Bir eylemin taklidi öykü için yapılır yani öykü taklidin objesine dönüşür.

Aristoteles'in Poetika'sının (1450a 3-5) Süryanice tercümesi ise şöyledir: "Sonra anlatıma dayalı öykü taklittir. Öykü ile ben olayların kompozisyonunu kastediyorum." Süryani mütercimin metninde yer verilen "anlatıma dayalı öykü" ifadesinde; anlatılan olay bir eylemi değil bir anlatıcıyı gerektirmektedir. Süryanice tercüme takip edilirse taklit; anlatıma dayalı bir hikâyenin öyküsüdür. Dolayısıyla bir oyuncunun/aktörün performansını gerektirmemektedir. Süryani mütercimin tercümesinde tragedyanın dramatik unsuru ya da sahnede oynamaya ilişkin özellikleri nakledilmemiştir. Mettâ b. Yûnus ilgili cümleyi tercüme ederken Süryanice tercümede teatral performansa dair tek bir ipucu bulamamıştır. Mettâ'nın tragedya yorumu; bu bağlamda tekrar bir medih şiiri olarak işlemiş gibi görünmektedir. Süryanice metnin Arapça tercümesi şu şekilde yapılmıştır: "Öykü (el-hurâfe); teşbih ve muhakat olan söz (el-hadîs) ve kasas'tır. Ben öykü (el-hurâfe) ve hikâye (el-hikâye)

51 Ayyâd, Kitâbu Aristotâlis fiş-Şi'r, 49; Bedevî, Fennü'ş-Şi'r, 53.

52 Aristoteles, Poetika (Şiir Sanatı Üzerine), çev. Samih Rıfat (Can Yayınları: İstanbul, 2010), 100. 
ile şeyleri (el-umur/durumları) terkip eden sözü (hadîs) kastediyorum." Mettâ b. Yûnus'un Süryanice "anlatıma dayalı öykü" ifadesinin benzer bir şekilde tercüme etmesi; yani anlatım yoluyla üretilen anlamlar; dramatik bir performansın izi olmaksızın çevrilmiştir. Hem Süryani mütercim hem de Mettâ tragedyanın performansa dayalı yönlerine atıfları değiştirmiş, anlatıma dayalı özellikler içinde açılamışlardır.

Aristoteles'in Poetika'sının farklı paragraflarında tragedyanın eylemin taklidi olduğu ya da eylemde bulunan insanlar tarafından oynandığı ifade edilmektedir: Filozofun asıl ilgisi sahnedeki trajik aktörlerin performansıdır. Tragedyanın temel parçası olan öyküyü oluşturan taklit edilmiş eylemler; oynayanlar yani oyuncular/aktörler ile ilgilidir. Aristoteles Poetika'da (1449b 31-33) "taklidi eylem içindeki kişiler yapar" ifadesi ile tragedyanın eylemde bulunan insanlar tarafından oynandığına dikkat çekmektedir. Bu cümlenin süryanice tercümesinde oyuncular/aktörler ve onların oyunları/performansı hakkında bir ifade yer almamaktadır. $\mathrm{Bu}$ cümlenin Süryanice tercümesi ise şöyledir: "Taklit bir eylemdir, tragedya anlatan kişiler tarafından anlatılır." Sonuç olarak tragedyanın dramatik yönü Süryanice tercümeler içinde orijinaline mutabık olmaksızın işlenmiştir. Hem tragedya hem komedya teatral oyunlardan çok, ezberden anlatılan parçalar olarak yorumlanmıştır. Dolayısıyla tragedya "eylemde bulunan insanlar tarafindan yapılan bir taklittir" ifadesi Süryanice farklı bir şekilde yorumlanmış; mütercim aktörlerin performansına yapılan atıfları gözden kaçırmış, dikkate almamıştır. Aristoteles'in Poetika'sından uzaklaşan bu tür tercümeler hem Süryani mütercimin ve Mettâ b. Yûnus'un tragedya ve komedya konusundaki kendi yorumlarını kattığını göstermektedir. "Süryani mütercim"; tragedyayı anlatıma dayalı tür; Mettâ ise tragedyayı medih şiiri olarak yorumlamıştır.

İbn Sînâ, muthos için öykü (el-hurâfe) ve kurgusal şiirsel sözler (ekavîl şi'riyye ve'lhurâfiyye) karşıllı̆ını vermiştir. İbn Sînâ iki terimi; "mesel ve hurâfe şi'riyyeh" birbirini tamamlayan bir tarzda metninin bütününde kullanılmıştır. ${ }^{53}$ ỉbn Rüşd, elhurâfe terimini kullanmakta ve öyküyü şöyle tanımlanmaktadır: "Kıssa anlatıcısı ve hikâyeci'nin, kıssasının ve hikâyesinin/konuşmasının, şu iki özelliği yani 'teşbih ve taklit' ile ortaya konmuş bir öyküyü ifade etmesi gerekir. Ben öykü ile şunu kastediyorum: Taklit ile kastedilen şeylerin terkibidir ki; [bu] ya onların kendilerinde olan şeylere göredir. -Ben var olanı kastediyorum.- Ya da yanlış olsa bile, genellikle şiirde ifade edilen bu şeylere göredir. Bu şiirsel sözlere öyküler denilmesinin nedenidir. Öyleyse kıssa anlatan kişiler ve hikâyeciler genellikle adetleri [karakterleri] ve inançları (itikadât) taklit etme yeteneğine sahip olan kişilerdir.. ${ }^{54}$

53 İbn Sînâ, "Fennü'ş- Şi'r", 171.

54 İbn Rüşd, "Telhîsu Kitâbi Aristûtâlîs fi'ş-Şi'r’", 230. 


\subsection{1. Öykünün Öğeleri: Baht Dönüşü/İdâre-İş̧timâl (Peripeteia), Tanın- $\mathrm{ma} /$ İstidlâl-Delâlet (Anagnorisis)}

Aristoteles öykünün iki ögesini; peripeteiea ve anagnorisis olarak vermektedir. Aristoteles'e göre peripeteia ve anagnorisis tragedyanın olay örgüsünün olmazsa olmaz unsurlarıdır: Peripetetia; "bahtın tersine dönmesi" ya da "her şeyin birdenbire hiç hesapta yokken -iyi ya da kötü anlamda tersine dönmesi"dir. Anagnorisis ise "sarsıcı bir buluş ya da anî bir kavrayışla bilgiye erme" ya da "birden ayrımına varma", "birdenbire fark etme anlaminda tanı(n)ma/bil(in)me'dir". ${ }^{55}$

İlk Arapça tercümede ve İslam filozoflarının metinlerinde peripetetia; deveran, idâre, iştimâl terimleri ile anagnorisis ise istidlâl, delâlet terimleri ile karşılanmıştır.

\section{Öykünün Bölümleri: İştimâl (Peripeti), Tanınmadır/Delâlet (Anagnorisis)}

\begin{tabular}{|l|l|l|l|}
\hline Aristoteles & Mettâ b. Yûnus & İbn Sînâ & İbn Rüşd \\
\hline Peripetetia & Deveran & İștimâl & İdare \\
\hline Anagnōrisis & İstidlâl & Delâlet/istidlal & İstidlâl \\
\hline
\end{tabular}

Mettâ deveran/ el-İdâr $e^{56}$ terimini Aristoteles'in peripeteia terimini tercüme etmek için kullanır, istidlâl terimini Aristoteles'in anagnorisis terimini tercüme etmek için kullanir.

İbn Sînâ'ya göre bir öykünün bölümleri iki tanedir: Birincisi iştimâl (peripeti/eylemlerin tam tersine dönmesi/baht dönüşleri); zıttan zıdda bir aktarmadır/geçiştir (intikâl). İbn Sînâ iştimâli Arap dilinde mutâbakat olarak adlandırılan türe benzetmektedir. Yunanlılar ise tragedyalarında iştimâli, çirkin bir halden, güzel bir hâle tedricî olarak nakl etmede kullanmaktadır. Bu intikâl güzel olmayan bir hâli çirkinleştirmek yoluyla ve bundan sonra da güzel olanı daha güzelleștirmek yoluyla yapılabilir. Yapılan bu şey; "yalanlama”, "azarlama” ve "tasdîk (takrîr) etmeye" benzer.

İbn Sînâ öykünün ikinci bölümünü “tanınmadır/delâlet (anagnorisis)” olarak açıklamaktadır: "O güzelleştirmek yoluyla güzel bir hale yönelmektir -tahsînin zıddı olan takbîh/çirkinleştirme yoluyla değil-." İbn Sînâ Retorik'e ait terimlere atıf yapmaktadır. Bunlar güzelleştirme ve çirkinleştirmedir. Nitekim filozofun İștimal ve delâlet/istidlâli açıklama teşebbüsü, Poetika üzerine Retorik konuların yerleştirilmesinin karakteristik örnekleridir. İbn Sînâ, Aristoteles'in peripeteia (iştimâl, baht dönüşleri) kavramını açıklamaya teşebbüs ettiği her durumda tahsîn, takbîh kavramlarına müracaat etmektedir. ${ }^{58}$

\footnotetext{
55 Aristoteles, Poietika (Şiir Sanatı Üzerine), 113.

56 Ayyâd, Kitâbu Aristotâlis fiş-Şi'r, 55.

57 İbn Sînâ, “Fennü’ş- Şi'r", 176.

58 Aristoteles, Retorik, çev. Mehmet H. Doğan (İstanbul: Yapı Kredi Yayınları, 1995), 183.
} 
İbn Rüşd'e göre taklite dayanması bakımından öykü içeren kavillerin (el-ekâvîl hurâfiyye) iki parçası vardır. Her taklit ya kendi zıddını taklit etmekle başlayarak taklide hazırlanır sonrada [ona uygun olan] taklide nakledilir. Bu Yunanlılar arasında idare (=peripeteia-baht dönüşü) olarak bilinmektedir. Ya da onun zıddının taklidini sunmaksızın, o şeyin kendisi taklit edilir. Bu istidlâl (=anagnōrisis-tanınma) olarak adlandırılmaktadır. Bu parçalar; taklide dayalı öykü içeren ifadelerin, asıl unsurları ve kuruluşunda yer alan parçalardır. İbn Rüşd Mettâ'nın deverân terimi idare'ye dönüştürmektedir. ${ }^{59}$

\section{2. Adât/Adetler (Karakter)}

Aristoteles karakteri (ethos) eylemde bulunan kişilere kendisi bakımından bir nitelik yüklediğimiz şey olarak tanımlamaktadır. Karakter söylev içerisinde açığa vurulması bakımından ahlakî olarak seçilen kişidir. Yunanca ethos kelimesi genellikle 'karakter' olarak tercüme edilmiştir. Fakat etimolojik olarak ona yakın olan heksis teriminin anlamlarını da (huy, hal, durum, karakter, karakteristik özellik, alışkanlık) içermektedir. Mettâ'nın tercümesinde adetler (adât) medhin ikinci parçası olarak zikredilmektedir. 'íbn Sînâ Poetika'sında tragedyanın bir parçası olarak yer verdiği adât/âdetler' kelimesi, hem 'ahlakî niteliklere' hem de onlar tarafından motive edilen 'eylemlere' işaret etmektedir. İbn Sînâ' adât/âdetler'i şöyle açılamaktadır: "Tragedya insanların bizâtihi kendilerinin taklidi değil onların âdetlerinin, fiillerinin, hayat tarzlarının ve mutluluklarının taklididir. Tragedyada fiilleri konuşmak, ahlakî nitelikleri konuşmaktan daha önemlidir/çoktur. Onlar ahlakî nitelikleri anlattıklarında fiiller için anlattılar. Böylelikle [Aristotleles] ${ }^{60}$ bölümler içerisinde ahlakî nitelikleri anlatmadı/lar fakat âdetleri; hem fiilleri hem de ahlakî nitelikleri açıkça içerecek şekilde anlattılar. Şöyle söylenebilir: Ahlakî nitelikler, bu tür fiilleri içine almaz. Fiiller onların tragedyalarında zorunlu olarak anlatıldı, ahlakî niteliklere gelince tragedyalarında anlatmak zorunlu değildir." ${ }^{61}$

İbn Rüşd adât kelimesinin kullanımında İbn Sînâ'yı takip etmektedir: Hem eylemleri hem de ahlakî özellikleri içermektedir: Medhin altı parçasından birini 'adet/karakter' oluşturmaktadır. Adetler kendisinde taklidin kullanıldığı ilk şeydir yani taklit edilen şeydir. İbn Rüşd'e göre 'adetler" [ve 'inançlar] medhin en önemli parçalarıdır. Çünkü medih sanatı, insanların kendilerini, duyularla algılanan bireysel varlıklar olmaları bakımından taklit eden bir sanat değildir. Aksine insanlar, güzel adetleri, güzel fiilleri/karakterleri, ve mutlu itikatları bakımından taklit edilir. Adetler/karakterler fiilleri ve ahlakî özellikleri içerir. ${ }^{62}$

\footnotetext{
59 İbn Rüşd, “Telhîsu Kitâbi Aristûtâlîs fi'ş-Şi'r”, 210.

60 Dahiyat, Avicenna's Commentary on the Poetics of Aristotle, 92.

61 Taşkent, İbn Sînâ ve Fârâbînnin Poetikaları, 112, 113.

62 İbn Rüşd, “Telhîsu Kitâbi Aristûtâlîs fi'ş-Şi'r”, 210.
} 


\subsection{Düşünce/Görüş (Re'y) itikat (İtikad).}

Tragedyanın üçüncü unsuru “düşüncedir” (dianoia). Aristoteles düşünceyi "kendisiyle konuşanların bir şey kanıtladığı ya da genel bir hakikate ifade verdikleri şey" olarak tanımlamaktadır. Ífade ile ortaya konan; iddia, yalanlama ve genellemelerdir. Mettâ medih sanatının üçüncü parçasını itikad (inanç) terimi ile tercüme etmiştir. ${ }^{63}$ İbn Sînâ da düşünceyi/görüş $\left(r e^{\prime} y\right)$ tragedyanın üçüncü parçası olarak olarak tartışır. ${ }^{64}$ Düşünceye ait söz, kendisinde istenilen şeye bir davet ve sakındırmaya yer vermeksizin var olan ya da var olmayan şeyler hakkında düşünceye teşvik eder. İbn Sînâ re'y ile tahyîli karşılaştırmakta sonrasında inançları ikna yoluyla ruhta yerleştirmeye katkısı olması bakımından hitabet ile ilişkilendirmektedir. Buna göre tahyîl, ruhu sıkmaya ve rahatlatmaya doğru hazırlayıcıdır. Antik dönemdekiler şiirî tahŷ̂li, inançları ruhta yerleştirmek için kullanıyorlardı. Daha sonra hitâbet ortaya çıktı ve böylelikle onlar inançları ikna yoluyla ruhta yerleştirmeye yöneldiler. ${ }^{65}$

İbn Rüşd medih sanatının üçüncü parçası olarak itikatı tartışır ve Mettâ da olduğu gibi itikat terimini kullanır. İbn Rüşd'e göre itikat var olan ve var olmayan şeyleri belli bir tarzda taklit etme yeteneğidir. Bu hitabetin var olan ya da var olmayan şeylere dair üstlendiği açıklamalara benzemektedir. Ancak hitabet bunu ikna edici kavillerle şiir ise taklide dayalı kavillerle yapmaktadır, filozof bu tür taklidin dinî kavillerde var olan bir şey olduğunu söylemektedir. Nitekim eski devletler de hitabet yolunu buluncaya kadar, 'itikatları' şiirsel kaviller yoluyla ruhlarda yerleştirmişlerdir. İtikada teşvik eden kavl, sadece var olan ya da var olmayan bir şeye teşvik etmektedir. ${ }^{66}$

\section{4. Mekûle (Söz ), Mukâbele, Ölçü (Vezn)}

Aristoteles'in Poetika'sında leksis (sözel ifade) ile karşılanmaktadır. Mettâ, mekûle (söz, söylenen) olarak tercüme eder. Mettâ tercümesinde sözü (el-mekûle) ölçülü/ölçülendirilmiş (el-mevzûn) kelama atıfla ya da söz/söylenilenler ile vezinlerin kendisinin terkibine/kompozisyonuna (el-mekûle terkib el-evzân nefseh) atıfla açıklamaktadır. İbn Sînâ tragedyanın dördüncü parçası için "el-mukâbele" kelimesini kullanmakta ve el-mukâbele'yi şöyle açıklamaktadır: "Açıklaması yapılan temanın/amacın, kendisinde söyleneni bir ölçü ile ifade etmesidir”. ${ }^{67}$ İbn Rüşd, medhin dördüncü parçasını ‘ölçü/vezn (el-vezn) olarak verir. İbn Rüşd, Mettâ’nın ter-

\footnotetext{
63 Ayyâd, Kitâbu Aristotâlis fiş-Şi’r, 51.

64 İbn Sînâ, “Fennü'ş- Şi'r", 176.

65 Mettâ'nın tercümesinde bu şekilde yorumlanabilecek bir ifade bulunmamaktadır. İbn Rüşd bu konuda İbn Sînâ'yı takip etmektedir.

66 İbn Rüşd, “Telhîsu Kitâbi Aristûtâlîs fi'ş-Şi'r”, 233.

67 İbn Sînâ, “íbn Sînâ, Fennü’ş- Şi'r”, 179.
} 
cümesinde Aristoteles'in leksis yerine kullandığı el-mekûle (söz) terimi yerine vezn terimini kullanmaktadır. ${ }^{68}$

\subsection{Manzara, Nazar, Bahs ve Nazar, Nazar ve İhticac}

Aristoteles’in tragedyanın altı ögesi içinde zikrettiği opsis (sahne düzeni) terimini "manzara, nazar, nazar ve ihticâc" terimleri ile tercüme edilmiştir. Aristoteles'in Poetika'sındaki opsis'e Süryanice tercümede verilen karşllık sonraki tercüme ve yorumları etkilemiştir. Opsis terimi Yunan dünyasından alınan, alımlanan kültürde karşılığı olmayan yabancı kelimelerdendir. Mettâ'nın ve İbn Rüşd'ün medih olan/övgü şiiri olarak karşılık verdiği tragedya bir tiyatro oyunu olmaktan öte bir kişi tarafından anlatılan/söylenen bir tür olarak anlaşılmış bu sebeple tragedya ve komedya teatral yapısı olan türler olarak görülmemiştir. Aristoteles'in Poetika'sındaki opsisin geçtiği bölümlerin Süryanice tercümesi bu tür yaklaşımlarda etkili olmuştur. Aristoteles Poetika'da (1449b 31-33) “Tragedyanın zorunlu ve önce-

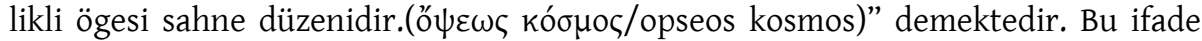
Süryaniceye şu şekilde tercüme edilmiştir: "Zorunlu olarak tragedyanın bir parçası yüzün güzelliği olabilir." ${ }^{69}$

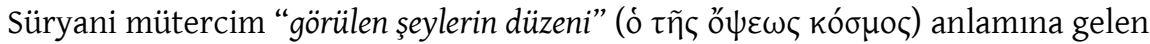
Yunanca ifadeyi "yüzün güzelliği” olarak tercüme etmiştir. Böylece Süryanicede güzellik/süsleme/bezeme anlamina gelen "hedrā" kelimesi, Yunanca dü-

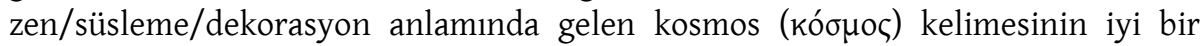
tercümesi olmuştur. Süryanice "yüz" anlamında gelen "parșōpā" kelimesi Yunanca görünüş/yön, yüz bakış ve görü karşılığı olan opsis (ö $\psi 1 \varsigma$ ) kelimesine uygun karşılık

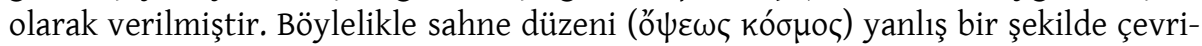
lerek paragrafta yerini almıştır. Kelimenin, Süryani mütercimin yaptığ1 gibi yüz olarak çevrilmesi yerine Yunanca opsis (ő $\psi \iota)$ ) kelimesinin karş1lığg olan "görülen şeyler" olarak karşılanması gerekirdi. Böylelikle set, sahne anlamına gelen kelime, yüzün güzelliği haline dönüşmüştür. Sonuç olarak Süryanice metinde tiyatroya yapılan diğer atıflar kaybolduğu gibi bu atıf da kaybolmuştur. ${ }^{70}$ Aynı cümlenin Arapçaya tercümesini Mettâ b. Yûnus şöyle yapmaktadır: "Medîh sanatının bir bölümünün zorunlu olarak ilki; bir yüzün (el-vech) güzelliğinin (cemâl) ve hüsnünün tasviri/tanımı (sıfat) olmasıdır."71

Tercüme edilen bu cümle ne Yunanca ne de Süryanice metnin tam olarak nakli değildir. Mettâ b. Yûnus'un cümleye eklediği tasvir, tanım, sıfat, nitelik karşılı̆̆ı verilebilecek "fi sıfatıhi" kelimesi ile ne kast ettiği belirsizdir. Belki de Süryanice tercümede yüzün karşılığı olarak kulllanılan “parșoppa” kelimesini, medih şiirinde övülen kişinin yüzünün anlatılması olarak yorumlamış olması mümkündür.

\footnotetext{
68 İbn Rüşd, “Telhîsu Kitâbi Aristûtâlîs fi'ş-Şi'r”, 237.

69 Rigolio, “Aristotle's Poetics”, 144.

70 Rigolio, “Aristotle's Poetics”, 144.

71 Ayyâd, Kitâbu Aristotâlis fiş-Şi’r, 49.
} 
Aristoteles Poetika'sının farklı bir paragrafında (1450 b15-20) tragedyanın altı ögesi içinde yer alan sahne düzenini (opsis) açıllamaktadır. Mettâ medhin altı ögesisi içindeki opsis'e el-manzar (görülen yer) karşılığını verir. Metnin devamında yer alan temsil ve oyuncuyu ise "el-ahz vucuh, münafık ve nifak" terimlerine müracaat ederek açıklar. ${ }^{72}$

İbn Sînâ, Mettâ'nın el-manzarü (görülen yer) kelimesine "nazar”, "bahs ve nazar", "nazar ve ihticâc” şeklinde farklı karşıllklar vermiștir. İbn Sînâ'nın metninde nazar kelimesi, Mettâ'nın metnindeki el-manzar ve Aristotelesin opsis terimine atfen görme ile ilgili bir terim (bakış/görünüş) olarak okunmuştur. ${ }^{73}$ Diğer taraftan opsis terimine filozofun verdiği diğer karş1lıklar (nazar, el-bahs ve'n-nazâr, nazar ve ihticâc) filozofun metninden yola çıkarak açıklanabilmektedir. İbn Sînâ tragedyanın ögeleri arasında "el-bahs ve'n-nazâr"1 saymaktadır. "Nazar"; bakış, bakma, göz ile görme, görme hissi (el-hissü’l ayn) manzara, görünüş, görüntü, görünüm anlamlar1na geldiği gibi anlayış, idrak, inceleme, tetkik, tahkik, düşünme anlamlarını da içermektedir. ${ }^{74}$ Bahs ise araştırmak, incelemek soruşturmak, müzakere etmek, tartışma, gözetleme, bakma, görüşme anlamlarına gelmektedir. ${ }^{75}$ İbn Sînâ taklidin yöneldiği şeyler içinde nazarı (en-nazar) zikretmekte ve söyle tanımlamaktadır: "Nazar'a gelince; ölçü ve melodi ile icra edilen, adet ve öykünün her birinin doğruluğunun açıklanması ve ispat edilmesine benzer." Farklı bir paragrafta ise "nazar ve ihticâc (delil getirme)" kullanılır ve şöyle tanımlanır: "Iffadenin anlamını ruhta yerleştiren şeylerdir. Onun kabulü, - kederi unutup teselli buluncaya kadar ve tragedyaya uygun duyguları üretinceye kadar- zorunludur. Onun kendisinde sanat yoktur. Yani Hitâbet kitabında zikredilen tasdîk/ikna, şiire uygun değildir."76

İbn Rüşd medih sanatının altı parçası içerisinde nazar terimini zikreder ${ }^{77}$ Nazarın anlamını şöyle açıklamaktadır: "Nazar (en-nazar) itikadın doğruluğunu açıklayan şeydir. Onlara göre övülen inançların doğruluğu için delil getirmenin (ihticâc) bir türü gibidir. Bunların hiçbiri Arap şiirinde yoktur ancak övülen şer'î kavillerde bulunur."78 İbn Rüşd farklı bir paragrafta nazarı tekrar şöyle açıklar: "Ben bir itikadın doğruluğu ya da bir eylemin doğruluğu için delil getirmeyi (el-ihticâc) kast ediyorum, o iknaya ait bir kavl değildir. Bu nedenle bu sanat için de uygun değildir.

\footnotetext{
72 Ayyâd, Kitâbu Aristotâlis fiş-Şi'r, 59.

73 Dahiyat, Avicenna's Commentary on the Poetics of Aristotle, 95.

74 İbn Manzur, “nazar”, Lisanü'l-Arab (İran: Neşru Edebi'l-Havze, 1405), 5 / 215.

75 İbn Manzur, “bahs”, Lisanü'l-Arab, 2/115, 116.

76 Retorik'te tartışılan ikna'ya atıf yapılmaktadır.

77 Opsis terimi hakkındaki tartışmalar için bkz. Charles E. Butterworth, Averroes' Middle Commentary on Aristotle's Poetics (Princenton: Princeton University Press, 1986), 76; Charles E. Butterworth, “Translation and Philosophy: The Case of Averroes' Commentaries" International Journal of Middle East Studies 26 (1994), 19-35; Gutas, “On Translating Averroes' Commentaries Averroes' Middle Commentary on Aristotle's Poetics", 92.

78 İbn Rüşd, “Telhîsu Kitâbi Aristûtâlîs fi’ş-Şi'r”, 210.
} 
Aksine sanat için uygun olan taklide dayalı bir kavldir. Şüphesiz şiir sanatı, özellikle de medih sanatı delil getirme ve münazara üzerine bina edilmez. Böylelikle medihte, -hitabetin kullandığı gibi- nifak [iki yüzlülük] sanatı ve al ahz bi'l vucuh'u kullanilmaz."

Mettâ b. Yûnus, İbn Sînâ'nın ve İbn Rüşd'ün metinlerinde yer alan "el-ahz bi'l vucûh", "nifak" ve "münafik" terimleri tragedyanın teatral özellikleri ile ilişki kurmaya imkân veren terimlerdir. Aristoteles Poetika'nın (1450 b15-20) opsis/sahne düzeni hakkındaki açıklamalarının devamında "tragedya sahnedeki temsilden ve oyuncudan bağımsız olarak da bir etkileme gücü vardır" ifadelerini kullanmaktadır. "El-ahz bi'l vucûh/yüzlerin alınması" ifadesi; 'rol oynamak, canlandırmak, oyun sergilemek, gösteri yapmak' anlamlarına geldiği gibi literal olarak karşılığı 'rol yapmak' ya da 'maske takmak'tır. Arapça el-aheze bil-vucûh ifadesi, oyuncu/aktör kelimesinin tercümesidir. Literal olarak ise hypokritoi'nin bir tercümesidir. Oyunculuk sanatı/rol yapma sanatı anlamina gelen ahz bil'vücuhu ise hypokrisis'in bir tercümesidir. ${ }^{80}$ Her iki Arapça ibare, Ebu Bişr Mettâ'nın Yunanca teknik terimleri, dolaylı bir ifade ile tercüme etme metodunun örneği olarak alınabilir. Bu ifade İbn Sînâ'nın ve Ebu Bişr Mettâ'nın 'eylemde bulunmayı', 'hypocrisis/nifak' olarak yorumlamasının ifadesidir. Bu iki terim bazen birlikte kullanılmıştır. İbn Sînâ aynı terimi, Yunanca hypocrisis'i, el-Hatâbe'de konuşma tarzı olarak; tragedyada ise 'eylemde bulunmak' olarak kullanmıştır. İbn Rüşd'de nifak [ikiyüzlülük] sanatı ve al ahz bi'l vucuh'u kullanmaktadır.

\subsection{Nağme Savt/Lahn/Telhîn}

Aristoteles Poetika'da harmonia terimini iki kez kullanır (1448b-20 ve 1449a-28). Filozof daha sonra terimi melos (ezgi-şarkl) ile ilişkilendirir ve en sonunda melopoiia (ezgi düzmek-şarkı yapımı) kelimesine dönüşür (1449b-33, 35, 1450a-10, 1450b-16). Harmoni ile melos [şarkı] ve melopoiia [şarkı yapımı] birbirinden farklı terimler olduğu dikkate alınmalıdır. Harmonia şiirin müzikal unsurlarını ritm ya da ölçüye ilişkin unsurlarından ayırmak için kullanılmaktadır. Aristoteles bu terimleri, hem şiirdeki müzikal unsurları, ritmik ve metrik unsurlarından ayırmak için kullanır hem de konuşmaya ilişkin unsurlardan ayırmak için kullanmaktadır. Aristoteles'in harmonia kavramı Mettâ b. Yûnus'un metninde farklı terimler ile çevrilmiştir. Ebu Bişr Mettâ'nın harmonia'yı ilk çevirisi nazm (düzen ya da düzenleme) sonraki ise te'lif (kompozisyon) şeklindedir. Ebu Bişr Mettâ telifi, İkinci ve üçüncü kez harmonia teriminin karşılığı olarak kullanır. Mettâ daha sonra harmonia'yı -melos ile beraber- savt ve nağme’ye dönüştürülür, "amel el-savt ve nağme”, "el-nağme ve elsavt" ve "sınaa el-savt" ifadeleri melopoiia'nın yerine kullanılmaktadır.

İbn Sînâ harmonia teriminin karşılığı olarak "lahn" kelimesini kullanmaktadır. İbn Sînâ Yunanca melopoiia kelimesini açıklamak için de lahn kelimesini kullanmak-

79 İbn Rüşd, “Telhîsu Kitâbi Aristûtâlîs fi'ş-Şi'r', 211.

80 Taşkent, íbn Sînâ ve Fârâbînin Poetikaları, 102. 
tadır. İbn Rüşd lahn'ın/melodi çoğul formu elhan'ı Aristoteles'in harmonia'sının karşıllı̆̆ olarak kullanmaktadır. İbn Rüşd telhis'te "el-nağme (ya da nagam)" "elnağme el-muttefika" ya da "el-nagam el-müttefika" kelimelerini de kullanmaktadır. El-nağme kelimesi Aristoteles'in metnindeki 'harmonia' terimine tekabül eden bir terimdir. İbn Rüşd metnin bazı bölümlerinde lahn terimini, Aristoteles'in harmonia ve melos arasındaki ilişkiyi muhafaza ederek ya da melopoiia terimini dikkate alarak kullanmaktadır. ${ }^{81}$

\section{Tragedyanın ve Methin Nicel Analizi}

Aristoteles tragedyanın nitel/iç ögelerinin yanı sıra nicel/dış ögelerini de ele almıştır. Bunlar "prolog, episodlar, exodos, koro şarkısı"dır. Mettâ, İbn Sînâ ve İbn Rüşd tragedya ve medhin nitelik (keyfiyyet) bakımından özelliklerini açıladıktan sonra nicelik (kemiyyet) bakımından özelliklerini anlatmaktadırlar. Mettâ "nicelik bakımından tragedyanın kısımları" başlığı altında hitabet ile karşılaştırarak "elmedhâl, mahrec er-rakkâs ve mecâz" ögelerini zikretmektedir. İbn Rüşd medih sanatını hitabet sanatı ile karşılaştırarak bazı ögelerini tartışmaktadır. İbn Sînâ Aristoteles'in metnindeki pek çok ögeyi açıklamaktadır. Aşağıda tragedyanın nicel ögeleri hakkındaki açıklamalarda İbn Sînâ'nın düşüncelerine yer verilmiştir. ${ }^{82}$

\subsection{Medhal}

Prolog, tragedyada koronun girişinden önce yer alan parçadır. Prologun fonksiyonu, tragedyanın ortaya koyduğu temel konuya ilişkin eylemler, durumlar hakkında izleyiciye/dinleyiciye bilgi vermektir. Bu bölüm dramatik tekniğin bir parçasıdır. Tragedyada hikâyenin sunumu yapılmayan parçası hakkında gerekli bilgileri taşıyan araçlardan biridir. İbn Sînâ medhal'i (prologue) parçalardan oluşan bütün bir bölüm olarak tanımladıktan sonra onun ortasında koronun, bir grup halinde icraya başladığını ifade etmektedir. Her tragedya bir başlangıç, orta ve sonucu (intiha) içerecek şekilde düzenlenmiş olan parçalara sahiptir. 'Şarkı (gınâ)' ve 'dans (raks)' bir grup tarafından icra edilir. Bu parça, Arap şiirinde 'medhal/giriş' (prolog) olarak isimlendirilen ve aşk şiirlerinin 'başlangıç/giriş (teşbîb/nesib) ${ }^{83}$ bölümünde yer alan parçaya benzemektedir. ${ }^{84}$

81 Harmoni, melos ve melopoiia terimleri için İbn Rüşd’ün Poetikası hakkında hazırladığımız Türkiye Bilimler Akademisi (TÜBA) tarafından yayın programına alınan çalışmada yer alan "Medhin öğeleri” başlı̆̆ı altındaki açıklamalara müracaat edilebilir.

82 İbn Rüşd'ün medih sanatının nicel öğeleri hakkındaki açıklamaları İbn Sînâ'dan oldukça farklı olduğu için yer verilmemiştir.

83 Nesîb ya da teşbîb geleneksel Arap şiirinin ilk parçasına yani başlangıç/girişine işaret etmektedir. Bu ilk parçada şair, genellikle bir aşk temasıyla ve kendi aşı̆̆ının niteliklerini vurgulayarak başlamaktadır. Hüseyin Elmalı, "Kaside”, TDV İslam Ansiklopedisi (İstanbul: Türkiye Diyanet Vakfı Yayınları, 2001), 24/ 562-564.

84 Taşkent, İbn Sînâ ve Fârâbînin Poetikaları, 125. 


\subsection{Mahreç er-Rakkas}

Parodos, Antik Yunan tragedyasında ve komedyasında koronun içeri girerken söylediği ezgidir. Parados; koronun ilk anlatımı, konuşma tarzıdır. Koronun fonksiyonlarından biri, gösterime ilişkin olmayan şey hakkında bilgi vermek olduğundan parados'un dramatik amacı, daha açık ve anlaşılır hale getirmektir. İbn Sînâ bu bölümü, kendisiyle dansçıların/koronun görünmeye başladığı ve 'mahrec errakkas' [koronun çıkış yeri, parodos; Antik Yunan tragedyasında ve komedyâsında koronun içeri girerken söylediği ezgi] olarak adlandırılan bir parça olarak ele almıştir. ${ }^{85}$

\subsection{Takvîm}

Stasimon; antik tiyatroda episodlar arasında söylenen lirik ezgidir. İbn Sînâ takvîmi (stasimon), başka yerde kullanıldığı gibi bir çeşit ritim (îkâ) olmaksızın icra edilen bir bölüm olarak tanımlamaktadır. Ağıt formundaki bir şarkının beraberinde ikaî bir eylem olmaksızın- sadece bir şiir vezni ile yüksek sesle okunarak icra edildiği bir parçadır. Bütün bunlar bir koro tarafindan (cemaat'ul mülhanîn) şarkı olarak söylenir. ${ }^{86}$

\subsection{Mecâz}

Episode, Antik Yunan tragedyasında iki tam koro şarkısı arasında kalan bütün bölümdür. İbn Sînâ episodu, mecâz ile karşılar. Şarkıcıların melodi (lahn) olmaksızın ritm (ikâ) ile icra ettikleri bölümdür. ${ }^{87}$

\subsection{Mahrec}

Arkasında artık hiçbir koro melodisinin, şarkısının olmadı̆̆ı bölümdür. İbn Sînâ exode terimini mahrec (exodos-çıkış) ile karşılamaktadır. Kendisinden sonra koronun şarkı söylemediği bölümdür. ${ }^{88}$

\section{Sonuç}

İslam filozoflarının kaleme aldıkları Poetikalar, Aristoteles'in poetik sanatlara dair yaklaşımını nasıl incelediklerini gösteren önemli metinlerdir. İslam filozoflarının, Aristoteles'in Poetika'sını kendi kültürel ve felsefî bakış açılarıyla değerlendirmeye yönelik müdakkik çabalarını dikkate almak gerekmektedir. Fârâbî, İbn Sînâ ve

85 Taşkent, İbn Sînâ ve Fârâbî’nin Poetikaları, 125.

86 Taşkent, İbn Sînâ ve Fârâbînin Poetikaları, 125.

87 Taşkent, İbn Sînâ ve Fârâbînin Poetikaları, 125.

88 Taşkent, İbn Sînâ ve Fârâbî’nin Poetikaları, 125. İbn Sînâ'nın tragedyanın tanımı ve tragedyanın nicel analizi konusunda özellikle "tragedyanın teatral unsurları" hakkında vermiş olduğu açıklamalar Aristoteles'in açıklamalarına oldukça yakın ve zengin bir içerik sunmaktadır. Bu konuda daha detaylı açıklamalar bu konuya tahsis etmiş olduğumuz çalışmamızda ele alınmıştır. 
İbn Rüşd'ün metinlerini doğrudan Aristoteles'in metni ile karşılaştırarak incelemek üç aşamalı bir süreci gerektirmektedir.

Birincisi: Yunanca-Süryanice-Arapçaya tercüme sürecinde Poetika metninin ne tür değişikliklere uğrayarak İslam filozoflarına nasıl intikal ettiğinin tesbit edilmesi,

İkincisi: İslam filozoflarının Aristoteles tarafından sunulan Yunan sanat formlarının yapısını çok yakından izlediklerinin tesbit edilerek metnin biçim ve içerik analizinin yapılması,

Üçüncüsü: Fârâbî ve İbn Sînâ'nın metinlerindeki bazı bölümlerde ifade edilen, özellikle İbn Rüşd'ün Poetika Telhis'inde belirginleşen Poetika'daki kavramların Arap/İslam kültür, edebiyat ve mantık düşüncesine sistematik olarak nasıl uyarlandıklarının belirlenmesi gerekmektedir.

Aristoteles'in Poetika's1, Arap kültürüne yabanc1 fakat Yunan dünyasında yaygın olan "dîsirambî, komedyâ, iyâmbû, drâmâtâ, aynî, dîkrâmî, sâtûrî, feyûmûtâ, efîkî rîtûrî, îficânâsâvus" gibi farklı formları içermektedir. Yapılan tercümeler beraberinde dil problemini getirmiştir. Nitekim metnin antik Yunan'dan başlayıp Süryanice ve Arapça tercümeler ile devam eden uzun yolculuğunda felsefî, kültürel, sosyal, entelektüel, dinsel farklılıların yanı sıra "zaman" ve "mekan" boyutları da dikkate alındığında, muhatap olunan metinde gerçekleşen değiş̧im ve dönüşümler kaçınılmaz hale gelmiştir. Bu kültürel ve zamansal mesafeler, Poetika'nın Yunancadan, Süryaniceye ve sonrasında Arapçaya nakil sürecinde kimi yanlış ve eksiklikleri içeren tercümeleri doğurmuş, tragedyanın teatral özellikleri tam olarak ifade edilememiş; bu sebeple Poetika'nın müteakip nakillerinde yanlış anlaşılmalar kaçınılmaz olmuştur. Bu konudaki kimi karışıklıklar, sözü edilen türler hakkında başlangıçta bilgi sahibi olmayan ya da tercihlerini bilinçli şekilde yapan mütercimler ve filozoflar için anlaşllabilecek bir durumdur. Severus Bar Şakko'nun Süryanice fragmanındaki țrāgodūtā ve qūmōdiyā kelimelerinin Mettâ'nın çevirisindeki dönüşümü, bir çeviri hatası ya da bilinçli bir tercih olarak değerlendirilebilecek olsa da karşılaştırmalı edebiyat çalışmaları için en özgün örneklerden biri olarak karşımızda durmaktadır. Mettâ'nın tercümesi ile başlayan, sonrasında Fârâbî, İbn Sînâ ve İbn Rüşd ile genişleyen telhîs/yorumlama ya da yeniden okuma/yazma sürecinde filozofların yaklaşımları birbirinden farklı olmuştur. Bu farklılıklar öncelikle filozofların farklı metinleri kullanması ile açıklanmaktadır: İbn Sînâ’nın Yahyâ b. Adînnin tercümesini, İbn Rüssd'ün ise Mettâ'nın metnini esas alması, telif edilen eserlerin içeriklerini birbirinden farklılaştırmıştır. Fârâbî ve İbn Sînâ, Aristoteles metnine daha sadık açılamalar yapmakta, Arapça'da yeterli karşıllı̆̆ bulunmayan ya da bilinmeyen Yunan sanat formlarına dair ibareleri transliterasyonu ile vermektedir. Buna karşılık Mettâ ve İbn Rüşd, Yunan dünyasına ait kimi konuları Arapça şiir türleriyle tanitan Kindî geleneğini takip ederek Yunan kültürüne has bir metnin Arapça konuşan bir topluma intibakını sağlamaktadır. İbn Rüşd'ün metninin bütünü dikkate alındığında, filozofun konuyu ele alış biçiminin Aristoteles'ten ve selefleri olan Fârâbî ve İbn Sînâ'dan farklılı̆̆ı, özellikle Arap şiirine ve Ku'ran ayetlerine 
müracaat ederek yaptığı açıklamalarda görülmektedir. Buna göre Poetika'ya iki temel yaklaşım biçimi söz konusudur: Birincisi Poetika çalışmalarının edebî ya da teatral özellikleri merkeze alınarak yapılan incelemelerdir. İkincisi ise "bağlam teorisi" olarak adlandırılan, Poetika'nın Retorika ile birlikte Mantık içinde değerlendirilmesidir. İslam filozoflarının tahyîl terimini merkeze alarak Poetika'yı mantık içinde değerlendirmelerinin dayanağı, tarihî süreç içerisinde Aristoteles şarihleri tarafından Poetika'nın Organon külliyatı içine dâhil edilmesidir. Bu her ne kadar Aristoteles'ten farklı olarak kendinden sonraki Grek yorumcuların verdiği Poetika bağlamı olsa da, İslam felsefesinde Poetika çalışmaları mantık içinde değerlendirilmiştir. Ancak sonraki süreçte İslam filozoflarının eserlerinin etkileri Mantık alanı ile sınırlı kalmamış, Poetikaların etkisi belagat ve tenkid çalışmalarında da izlenebilir olmuştur.

Çıkar Çatışması / Conflict of Interest: Yazar çıkar çatışması olmadığını beyan etmiştir. / The author declared that there is no conflict of interest.

Finansal Destek / Grant Support: Yazar bu çalışma için finansal destek almadığını beyan etmiştir. / The author declared that this study has received no financial support. 


\section{Kaynakça}

Aristoteles. Poetika - Şiir Sanatı Üzerine (Peri poiētikēs). çev. Nazile Kalaycı. Ankara: Pharmakon Kitap, 2012.

Ayyâd, Şükrî Muhammed. Kitâbu Aristotâlis fiş-Şi'r nakl Ebî Bişr Mettâ b. Yûnus elKunnâ̂i min'el-Süryânî ile'l-Arabî. Kahire: Dâru'l-Kitâbil-'Arabî, 1967.

Bedevî, Abdurrahman. Aristûtâlis Fennu'ş Şi'r, mea tercemeti'l-Arabiyyeti'l kadîmeti ve şurûhi'l- Fârâbî, İbn Sînâ ve İbn Rüşd. Beyrut: Dâru's-Sakafe, 1953.

Black, Deborah L.. Logic and Aristotle's Rhetoric and Poetics in Mediavel Arabic Philosophy. Leiden: E.J. Brill, 1990.

Butterworth, Charles E.. "Translation and Philosophy: The Case of Averroes' Commentaries”. Int. J. Middle East Stud. 26 (1994), 19-35.

Butterworth, Charles E.. Averroes' Middle Commentary on Aristotle's Poetics. Princeton: Princeton University Press, 1986.

Cantorino, Vicente. Arabic Poetics in the Golden Age; Selection of Texts, Accompanied by a Peliminary Study. Leiden: E. J. Brill, 1975.

Dahiyat, M. İsmail. Avicenna's Commentary on the Poetics of Aristotle: A Critical Study with an Annotated Translation of the Text. Leiden: E. J. Brill, 1974.

Durmuş, İsmail. "Hiciv”. Türkiye Diyanet Vakfı İslam Ansiklopedisi. 17/447-449. İstanbul: Türkiye Diyanet Vakfı Yayınları, 1998.

Durmuş, İsmail. "Methiye”. Türkiye Diyanet Vakfi İslam Ansiklopedisi. 29/406-408. İstanbul: Türkiye Diyanet Vakfi Yayınları, 2004.

Edzard, Lutz vd. "A new look at the Greek, Syriac, and Arabic versions of Aristotle's Poetics". Grammar as a window o Grammar as a window onto nto Arabic Humanism. A Collection of Articles in Honour of Michael G. Carter. Ed. Lutz Edzard -Janet Watson. 222-264. Wiesbaden: Harrassowitz, 2006.

Elmal1, Hüseyin. “Kaside”. Türkiye Diyanet Vakfi İslam Ansiklopedisi. 24/562-564. İstanbul: Türkiye Diyanet Vakfı Yayınları, 2001.

Endress, Gerhard. The Works of Yahyâ Ibn 'Adi. Wiesbaden: Reichert, 1977.

Goodman, L. E.. Avicenna-Arabic Thought and Culture. London: Routledge, 1992.

Gutas, Dimitri. “On Translating Averroes Commentaries Averroes' Middle Commentary on Aristotle's Poetics”. Journal of the American Oriental Society 110/1 (1990), 92-101.

Gutas, Dimitri. "The Poetics in Syriac and Arabic Transmission". Aristotle Poetics Editio Maior of the Greek Text with Historical Introductions and Philological Commentaries. ed. Leonardo Tarán vd. Boston-Leiden: Brill, 2012.

İbn Manzur. Lisanü'l-Arab. İran: Neşru Edebi'l-Havze: 1405. 
İbn Rüşd. “Telhîsu Kitâbi Aristûtâlîs fi'ş-Şi'r". Fennü’ş-Şi'r. nşr. Abdurrahman Bedevî. 201-251. Beyrut: Dâru's-Sakafe, 1953.

İbn Rüşd. Telhîsu Kitâbi Aristotâlîs fi'ş-şir. nşr. Charles E. Butterworth-Ahmet Abdülmecid Herîdî. Kahire: el-Hey'etü'l-Misriyyetü'l-'Amme li'l-Kitâb, 1986.

İbn Rüşd. Telhîsu Kitâbi Aristûtâlîs fi'ş-Şi'r. nşr. Muhammed Selîm Sâlim. Kahire: 1971.

İbn Sînâ. “Fennü'ş-Şi'r'. Fennü’ş-Şitr. nşr. Abdurrahman Bedevî. 161-198. Beyrut: Dâru's-Sakafe, 1953.

İbn Sînâ. Kitabu'l-Mecmû ev el-Hikmet'ül-Arûziyye. nşr. Muhsin Salih. Beyrut: Daru'lHâdi, 2007.

Kassel, Rudolf. Aristotelis de arte poetica liber. Oxford: Clarendon Press, 1965.

Kaya, Mahmut. Kindî: Felsefî Risaleler. İstanbul: Klasik Yayınları, 2002.

Kemal, Sâlim. The Philosophical Poetics of AlFârâbî, Avicenna and Averroes, The Aristotelian Reception. London-New York: Routledge Curzon, 2000.

Leezenberg, Michiel. “Katharsis, Greek And Arab Style. On Averroes's Misunderstanding Of Aristotle's Misunderstanding of Tragedy". Rereading Classics in 'East' and 'West' Post-colonial Perspectives on the Tragic. ed. Freddy Decreus vd. 300-316. Gent: Documentatiecentrum voor Dramatische Kunst Gent, 2004.

Margoliouth, D. Samuel. Analecta Orientalia ad Poeticam Aristoteleam. London: D. Nutt, 1887.

Nedim, Muhammed b. İshak. El-Fihrist. çev. Ramazan Şeşen. İstanbul: Türkiye Yazma Eserler Kurumu Başkanlığı Yayınları, 2019.

Okay, Orhan M. “Hiciv”. Türkiye Diyanet Vakfi İslam Ansiklopedisi. 17/449-450. İstanbul: Türkiye Diyanet Vakfı Yayınları, 1998.

Rigolio, Alberto. “Aristotle's Poetics in Syriac And in Arabic, Translations: Readings of Tragedy”. Khristianskii Vostok 6 (Христианскиŭ Восток NS 6). 140-149. Moscow: Russiian Academy of Sciences, 2013.

Tarán, Leonardo vd. Aristotle Poetics, Editio Maior of the Greek Text with Historical Introductions and Philological Commentaries. Leiden-Boston: Brill, 2012.

Taşkent, Ayşe. Güzelin Peşinde, Fârâbî, İbn Sînâ ve ibn Rüşd'de Estetik. İstanbul: Klasik Yayınlar1, 2012.

Taşkent, Ayşe. İbn Sînâ ve Fârâbînnin Poetikaları Aristoteles'in Poetika'sının İslam Dünyasındaki Yansımaları. Ankara: Türkiye Bilimler Akademisi, 2019.

Tkatsch, Jaroslaus. Die arabische Übersetzung der Poetik des Aristoteles. Vienna: Akademie der Wissenschaften, 1928.

Yusufî, Muhammed Latifî. eş-Şi'r ve'ş-şi'riyyeh, el-felâsife ve'l-müfekkirûne'l-Arab. Tunis: Dârü'l-Arabiyye li'l-Kitâb, 1992. 


\section{Tragedy in the Islamic World in the Context of Aristotle's Poetics: Tragedy in Greek, Syriac, and Arabic Translations, Commentaries, and Summaries}

\section{Extended Abstract}

Islamic philosophers have written important texts that build upon Aristotle's approach to the poetic arts. I examine texts written by al-Fārābī, Ibn Sīnā, and Ibn Rushd on poetics and compare them with Aristotle's Poetics using a three-stage process. First, I try to determine what kind of changes were made to the Poetics in the process of its translation from Greek into Syriac and Arabic. Second, I examine how closely Islamic philosophers followed the structure of the Greek art forms presented by Aristotle and the form and content of his Poetics, discussions of which are found in the texts of Fārābī, Ibn Sinnā, and especially Ibn Rushd's Talkhis. In this three-stage process, my goal is to determine how concepts in Aristotle's Poetics were systematically adapted to Arab / Islamic culture, literature, and thought.

In the poetics literature in the Islamic world, two translators of Aristotle's Poetics stand out: Abū Bišr Mattā ibn Yūnus (d. 940) and Yahyā ibn Adī (d. 975). The text of Abū Bišr's translation from Syriac to Arabic survives today in the Arabic manuscripts section of the Bibliotheque Nationale in Paris (2346 arabe [fol.131a146b]). This translation, completed in the year 932, is based on the Syriac-Aramaic translation of a lost Greek manuscript dating from about 700 years earlier. Besides this Arabic translation, only a passage of about thirty lines survives from the Syriac translation. The passage is quoted in Jacob bar Šakko's Book of Dialogues.

In the process of transferring Poetics from Greek to Syriac and later to Arabic, incomplete and inaccurate translations were made. Because the Syriac translator and Abū Bišr did not know Greek arts and tragedy, their translations failed to express the theatrical features of tragedy, the absence of which had a great impact on subsequent transmissions and led to a misunderstanding of the Poetics. A comparison of the definitions of tragedy in the Syriac fragment of Jacob bar Šakko and the translation of Abū Bišr provides important data about early translations. The most important change Abū Bišr made in his Arabic translation was to translate tragedy as "the art of madīh" (sināat al-madīh). Abū Bišr adapted the words trāgodūtā and qūmōdiyā in Syriac to a form that existed in Arabic literature. Abū Bišr used the terms madīh / praise for tragedy and hijā for comedy. Like Abū Bišr, Ibn Rushd translated tragedy as "the art of madih." But, as an examination of Ibn Rushd's text as a whole makes clear, his approach to the subject different greatly from Aristotle's. Drawing heavily on Arabic poems and Quranic verses, Ibn Rushd's statements were not based on tragedy, which is a Greek art, but on madih, a form of Arabic literature. Meanwhile, Ibn Sinnā used a different translation as his source, not 
the text of Abū Bišr but that of Yahyā ibn Adī, and he used the term tragedy not as the art of madih but in the original, with transliteration.

In the works of Abū Bišr, Ibn Sīnā, and Ibn Rushd, the six elements of tragedy in Aristotle's Poetics are generally translated as follows: muthos (myth) as khurāfah; ethos (character) as al-ādāt; lexis (measure) as wazn; dionoia (thought) as itikād; opsis (spectacle) as nazār; and harmonia (harmony) as lahn. In the explanations of these elements, the elements of tragedy based on theatrical performance are sometimes explained in association with poetry, rhetoric, or different narrative types. Aristotle treats tragedy in terms of its quantitative elements. In the text of Ibn Sinā, prologue becomes madhāl, exodos becomes makhraj, and metaphor and stasimon become taqwim. Aristotle's idea of catharsis did not play a central role in the interpretations of Ibn Sina and Ibn Rushd. The absence of emphasis on the psychological and emotional effects of catharsis in Islamic philosophers' definitions of tragedy can be explained contextually: for them, the purpose of poetic expression or literary form was not just to give pleasure, but to persuade the audience. The reason for this was likely related to the classification of rhetoric and poetics as parts of logic, which had to do with the process by which the Poetics entered in the Islamic tradition.

Aristotle wrote six books on logic: Categories (Categoriae), On Interpretation (De Interpretatione), Prior Analytics (Analytica Priora), Posterior Analytics (Analytica Posteriora), Topics (Topica), and Sophistical Refutations (De Sophisticis Elenchis). These were brought together under the name Organon, which means "instrument," during the Byzantine period. To these, Neo-Platonists and Syriac scholars later added Aristotle's Rhetoric and Poetics, increasing the number of books in the Organon to eight. With the addition of Isagoge, Porphyry's (d. 305) introduction to Aristotle's Categories, the number of books in the logic corpus increased to nine. The most important reason why Islamic philosophers treated poetics as a branch of logic is that the Poetics was included in the Organon corpus in the historical process. Poetics studies in Islamic philosophy were carried out within the framework of the discipline of logic and took on the "logical" color of the Arabic writing in that field, something not found in the original work.

Keywords: Aristotle, Poetics, Jacob bar Šakko, Abū Bišr Mattā ibn Yūnus, al-Fārābī, Ibn Sīnā (Avicenna), Ibn Rushd (Averroes), Tragedy, The Art of Madīh. 